\title{
COMPARATIVE ANALYSIS OF ANTIBIOTIC CONSUMPTION AMONG HOSPITALIZED CHILDREN IN MOSTLY COMMON SURGICAL CASES
}

Summary of Doctoral Thesis for obtaining the degree of a Doctor of Pharmacy Speciality - Clinical Pharmacy 
Inese Sviestiņa

\title{
COMPARATIVE ANALYSIS \\ OF ANTIBIOTIC CONSUMPTION AMONG HOSPITALIZED CHILDREN \\ IN MOSTLY COMMON SURGICAL CASES
}

\author{
Summary of the Doctoral Thesis \\ for obtaining the degree of a Doctor of Pharmacy
}

Speciality - Clinical Pharmacy

Scientific supervisor:

Dr. med., Associate Professor Dzintars Mozgis

Riga, 2015 
Doctoral thesis performed at: University Children's Hospital

Scientific supervisor:

Dr. med., Associate Professor Dzintars Mozgis,

Department of Public Health and Epidemiology,

Rīga Stradinš̌ University

Official reviewers:

Dr. pharm., Assistant Professor Dace Bandere,

Department of Pharmaceutical Chemistry,

Rīga Stradinsš University

Dr. med., Professor Uga Dumpis,

Faculty of Medicine, University of Latvia,

Pauls Stradins Clinical University Hospital

Dr. med., Professor Rolanda Valintèlienè,

Institute of Hygiene, Lithuania

Defence of the Doctoral Thesis will take place at the public session of the Doctoral Committee of Pharmacy on 16 December 2015 at 15.00 in the Hippocrates Lecture Theatre, 16 Dzirciema Street, Rīga Stradiṇš University.

Doctoral thesis is available in the library of RSU and RSU homepage: www.rsu.lv

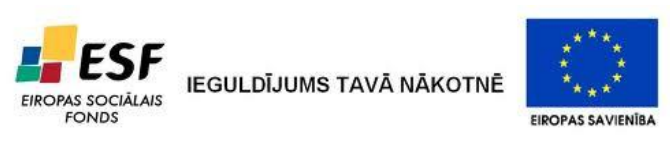

The doctoral studies were supported by European Social Fund project No. 2009/0147/1DP/1.1.2.1.2/09/IPIA/VIAA/009

"Support for the Acquisition of Doctoral Study Programmes and Scientific

Degree at Rīga Stradiņš University"

Secretary of the Doctoral Committee:

Dr. pharm., Assistant Professor Dace Bandere 


\section{TABLE OF CONTENTS}

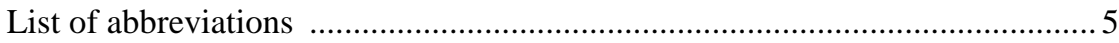

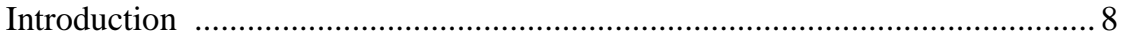

Aim of the study

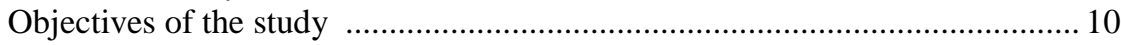

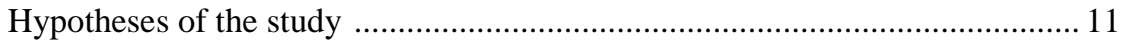

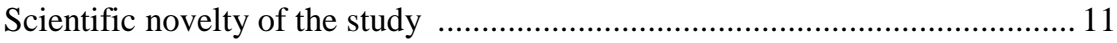

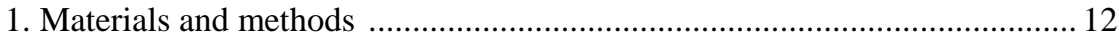

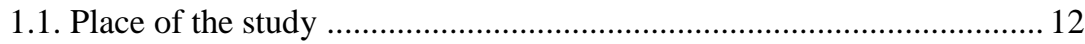

1.2. Analysis of antibiotic consumption at the University Children's

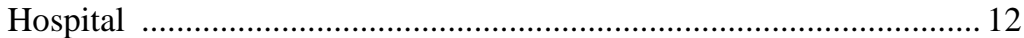

1.2.1. Point prevalence survey ............................................................ 12

1.2.2. Antibiotic analysis by using defined daily dose method ............... 14

1.2.3. Analysis of antibiotic drug utilization (90\%DU) .......................... 15

1.3. Analysis of perioperative antibiotic prophylaxis and treatment in patients with most common surgical cases ........................................ 16

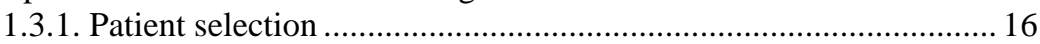

1.3.2. Analysis of surgical prophylaxis ................................................ 16

1.3.3. Analysis of prescribed antibiotic doses in the Paediatric Surgery

Clinic and dosing errors in antibiotic prescribed for surgical patients .... 17

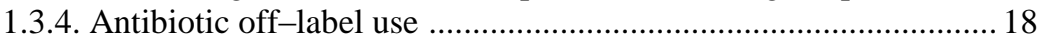

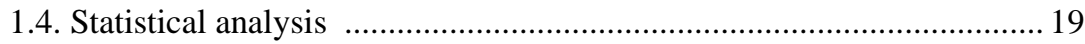

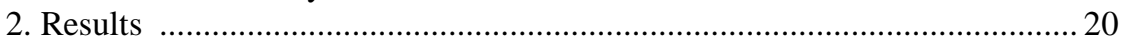

2.1. Results of point prevalence surveys ………….................................. 20

2.1.1. Results of point prevalence surveys at the University Children's

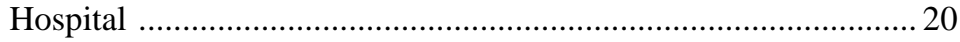

2.1.2. Antibiotic consumption at Latvian hospitals ................................ 24

2.2. Antibiotic consumption by using defined daily dosage method ........... 24

2.2.1. Antibiotic consumption in the hospital ....................................... 24

2.2.2. Antibiotic consumption in hospital wards .....................................29

2.2.3. Antibiotic consumption at the Paediatric Surgery Clinic .............. 29

2.3. Antibiotic consumption 90\%DU analysis ......................................... 30

2.4. Acute appendicitis: the patients' characteristics and analysis of the

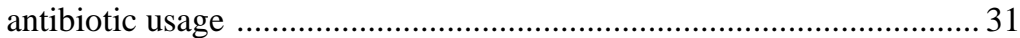

2.4.1. The patients and surgeries' characteristics and analysis of prophylaxis and treatment ............................................................... 31

2.4.2. Analysis of the dosages of the most commonly used

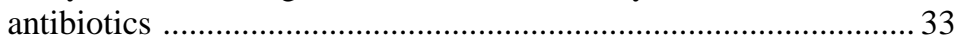

2.4.3. Antibiotic off-label use ............................................................. 34

2.5. Mesadenitis: the patients' characteristics and analysis of the antibiotic usage 
2.5.1 Patients' characteristics and treatment analysis

2.5.2. Analysis of antibiotics most commonly used in the mesadenitis treatment

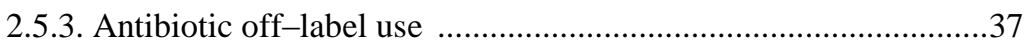

2.6. Injuries of upper and lower extremities: patients' characteristics

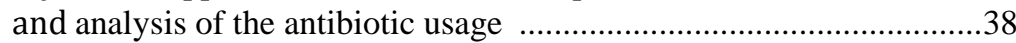

2.6.1. Characteristics of patients and surgeries, and analysis of the surgical prophylaxis

2.6.2. Analysis of the most commonly used antibiotics for surgical prophylaxis

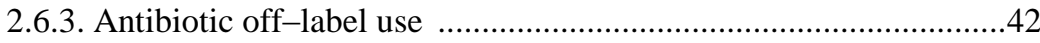

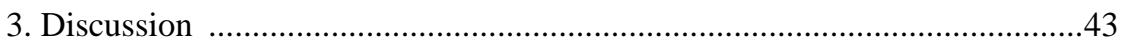

3.1. The usage of point prevalence surveys in the antibiotic consumption analysis

3.2. The usage of the methodology of the defined daily dosage in antibiotic consumption studies

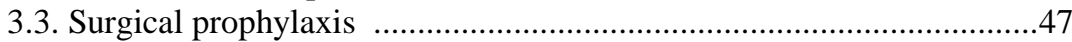

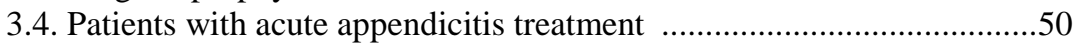

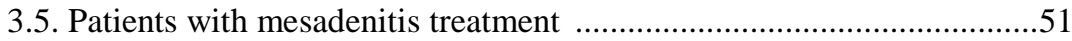

3.6. Resources of the medicines information ...........................................52

3.7. Antibiotic prescription problems at the UCH Paediatric

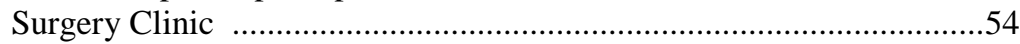

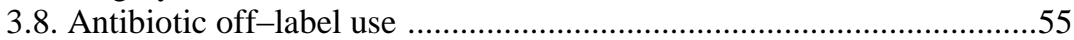

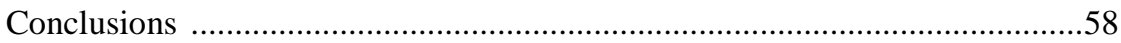

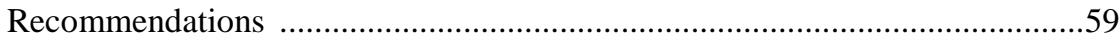

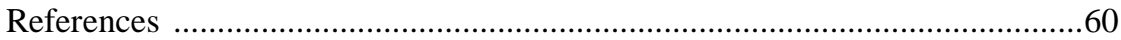

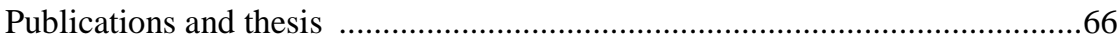




\section{LIST OF ABBREVIATIONS}

AAP - American Academy of Pediatrics

$\mathrm{AB}-$ antibiotics

ACCP - American College of Clinical Pharmacy

ARIKK - Coordination Committee for Antimicrobial Resistance Limitation (abbreviation from Latvian, Antimikrobās rezistences ierobežošanas koordinācijas komisija)

ARPEC - Antibiotic Resistance and Prescribing in European Children

ATC - Anatomical Therapeutic Chemical classification system

BARN - Baltic Antibiotic Resistance collaborative Network

$\mathrm{BD}$ - bed days

BNFC - British National Formulary for Children 2013-2014

$\mathrm{CI}$ - confidence interval

DDD - defined daily dose

DDD/100 GD - defined daily dose per 100 bed days

DDD/100 patients - defined daily dose per100 treated patients

$90 \%$ DU - antibiotics, which accounted for $90 \%$ of the total volume of use (drug utilization)

EAHP - European Association of Hospital Pharmacists

ECDC - European Centre for Disease Prevention and Control

ESBL - Extended spectrum beta lactamase

ESCP - European Society of Clinical Pharmacy

ESPID - European Society for Paediatric Infectious Diseases

FIP - International Pharmaceutical Federation (abbreviation from French, Federation Internationale Pharmaceutique)

HMA - Heads of Medicines Agencies

Hospital Recommendations - UCH Recommendations for surgical prophylaxis I88 - Nonspecific lymphadenitis 
ICD - International Classification of Diseases, $10^{\text {th }}$ revision

IM - intramuscular

INESSS - National Institute for Health and Social Services Excellence (abbreviation from French, Institut national d'excellence en santé et en services sociaux)

IV - intravenous

HAI - healthcare-associated infections

K35 - acute appendicitis

$\mathrm{kg}$ - kilograms

Lexi - Pediatric and Neonatal Dosage Handbook

$\mathrm{mg}-$ milligrams

NICE - National Institute for Health and Clinical Excellence

NICU - Neonatal Intensive Care Unit

$\mathrm{O}-$ oral

PICU - Paediatric Intensive Care Unit

PPS - point prevalence survey

QTR - quarter

RSU - Rīga Stradinsš University

$\mathrm{S} 42$ - Fracture of shoulder and upper arm

S52 - Fracture of forearm

S62 - Fracture at wrist and hand level

S72 - Fracture of femur

S82 - Fracture of lower leg, including ankle

S92 - Fracture of foot, except ankle

SAAGAR - South Australian expert Advisory Group on Antibiotic Resistance SAM - State Agency of Medicines of the Republic of Latvia

SCHTA - Swedish Council on Health Technology Assessment

$\mathrm{SD}$ - standard deviation

SFAR - French Society of Anaesthesia and Intensive Care (abbreviation from 
French, Société Française d'Anesthésie et de Réanimation)

SIGN - Scottish Intercollegiate Guidelines Network

SPC - Summary of Product Characteristics

SSI - Surgical Site Infection

UCH - University Children's Hospital, Riga

USA - United States of America

USG - ultrasonography

WHO - World Health Organization

WHOCC - WHO Collaborating Centre for Drug Statistics Methodology 


\section{INTRODUCTION}

Growing antimicrobial resistance has been recognized as a worldwide threat to public health (McLoughlin et al., 2005, Raveh et al., 2007). This is why new solutions are needed to improve $\mathrm{AB}$ use. According to some studies up to $60 \%$ of $\mathrm{AB}$ are used incorrectly in hospitals (e.g., the use of broadspectrum $A B$ instead of narrow-spectrum $A B$, the administration of intravenous $\mathrm{AB}$ instead of use of or switch to oral $\mathrm{AB}$ ) (Davey et al., 2005). One of the latest WHO reports of AB resistance states that "there are significant gaps in surveillance, and a lack of standards for methodology, data sharing and coordination" (WHO, 2014). The Ministry of Health of the Republic of Latvia has founded the "Coordination Committee for Antimicrobial Resistance Limitation" (Veselības ministrijas rīkojums Nr. 100, 2013), which aim is to introduce the National plan on $\mathrm{AB}$ resistance, as well as correct and rational use of $\mathrm{AB}$ in Latvia $(A R I K K, 2015)$. It is impossible to introduce correct and rational use of $\mathrm{AB}$ without identification of current situation in $\mathrm{AB}$ consumption.

There are limited amount of reliable data available on $\mathrm{AB}$ use in children in hospitals if to be compared with adult data, but $\mathrm{AB}$ are among the most frequently medicines administered to children (de Jong et al., 2009, Schindler et al., 2003). AAP guidelines (Dellit et al., 2007) states that only few of studies have focused on hospitalized newborns, children, as well as adolescents. The study performed in 40 paediatric hospitals across America established that during their hospital stay up to $60 \%$ of children received at least one antibiotic (Gerber et al., 2010). The study concludes that children at some hospitals were undertreated with $\mathrm{AB}$ and thus could be exposed to the risk of mistreatment, or that some hospitalized children have received excessive $A B$ therapy and thus were unnecessarily exposed to the risk of developing $A B$ 
resistant infections. The study performed in five children's hospitals in China during the period of time from 2002 to 2006 established that the most frequently used $\mathrm{AB}$ were the $3^{\text {rd }}$ generation cephalosporins, the extensive use of which could create preconditions for the developing antimicrobial resistance (Zhang et al., 2008a). It was only in 2012 when Europe had its first Europeanwide PPS on AB use in hospitalized paediatric patients (Versporten et al., 2013). Latvia was represented by nine hospitals and the author of this thesis collected AB consumption data from all participating hospitals. Systematic PPS was never conducted at the UCH. Therefore there was lack of comprehensive information on $\mathrm{AB}$ usage tendencies at the hospital.

The use of surgical antibiotic prophylaxis in children is not well described despite the fact that the study performed in the USA in 1982 (Kesler et al., 1982) established that $\mathrm{AB}$ prophylaxis was administered incorrectly. Since this study there have not been any significant changes. The authors still believe that almost half of all procedures of the surgical prophylaxis was not performed under the guidelines in. Most often than not the prophylaxis was unnecessary prolonged (Voit et al., 2005).

There were numerous audits performed in order to evaluate the appropriateness of the use of $\mathrm{AB}$ in surgical prophylaxis in adult populations, but there is still shortage of data regarding paediatric surgery (Hing et al., 2005). The study performed in 12 paediatric hospitals in Turkey establishes that inappropriate use of $\mathrm{AB}$ was the most common in surgery wards (Ceyhan et al., 2010). Similar conclusions were deduced from the study completed in Europe in 32 hospitals across 21 country (Amadeo et al., 2010). Rangel et al. have concluded that many children still do not receive prophylaxis when indicated, and an even greater proportion receives it when there is no indication (average 40\%; 10-83\%) (Rangel et al., 2011). Many of current guidelines are based on adult data (Rangel et al., 2011), but there is not enough evidence suggesting that these data could be used in children without any appropriate studies 
regarding this particular population (Tönz et al., 2000). Appropriate surgical antimicrobial prophylaxis could prevent post-operative SIS. However, inappropriate use of $\mathrm{AB}$ could increase the antimicrobial resistance, as well as costs for patients and hospitals (Paterson, 2006). Another fundamental problem is a common and well-known practice of $\mathrm{AB}$ off-label use especially in the paediatric population that mostly is related to the doses and indications (Porta et al., 2010).

\section{Aim of the study}

To examine $\mathrm{AB}$ consumption general tendencies in the $\mathrm{UCH}$ and to describe $A B$ use in the surgical prophylaxis and treatment in hospitalized children receiving most common surgical treatment.

\section{Objectives of the study}

1. To identify $\mathrm{AB}$ consumption and to determine the most fundamental $\mathrm{AB}$ consumption tendencies in the $\mathrm{UCH}$.

2. To analyse $A B$ surgical prophylaxis in most common surgical cases (appendicitis, mesadenitis, and upper and lower extremity injuries) at the UCH Paediatric Surgery Clinic.

3. To analyse prescribed $\mathrm{AB}$ and $\mathrm{AB}$ doses to patients in most common surgical cases at the UCH Paediatric Surgery Clinic.

4. To analyse $A B$ off-label use in most common surgical cases at the UCH Paediatric Surgery Clinic. 


\section{Hypotheses of the study}

1. The UCH has the high rate of the high risk $\mathrm{AB}$ consumption that could lead to the development of antimicrobial resistance.

2. The strategy of $\mathrm{AB}$ use in children in most common surgical cases at the UCH Paediatric Surgery Clinic differs from what is stated in the international guidelines.

3. Wrong $\mathrm{AB}$ doses are most frequently prescribed to children under the age of 12 years.

\section{Scientific novelty of the study}

Until now in Latvia data on $\mathrm{AB}$ consumption in hospitalized children was never analysed separately from the data covering adult population. Also, this study is the first, which provides analysis on $\mathrm{AB}$ use in surgical prophylaxis and treatment of hospitalized children in most common surgical cases.

All the data presented in the study are the result of the author's own research, which was completed under the supervision of the scientific supervisor. The doctoral thesis "Comparative analysis of antibiotic consumption among hospitalized children in mostly common surgical cases" was presented on $20^{\text {th }}$ May 2015 during the faculty meeting at the Department of Pharmaceutical Chemistry, Rīga Stradinsš University. 


\section{MATERIALS AND METHODS}

\subsection{Place of the study}

The research was conducted at the University Children's Hospital.

\subsection{Analysis of antibiotic consumption at the University Children's Hospital}

\subsubsection{Point prevalence survey}

During the period from $1^{\text {st }}$ January 2011 to $31^{\text {st }}$ December 2013 twice a year (in May and November each year) in total there were six PPS conducted. In these PPS protocol developed and validated by ARPEC was used. Every ward was audited once. All beds in each administrative unit (department) were completely audited in a single day in order to calculate correctly the denominator (number of admitted patients). In order to capture information about prophylaxis during previous 24 hours Paediatric Surgical Wards were not to be surveyed on a Monday, but during the period from Tuesday to Friday. Paediatric Medical wards were surveyed during all week (from Monday till Friday). Various (mixed) departments (surgery and therapeutics) had also to be surveyed during the period from Tuesday to Friday. During PPS data on both patients in the ward and patients treated with $\mathrm{AB}$, as well as the total number of beds in the ward were collected. See Figure 1.1. for patient selection criteria. 


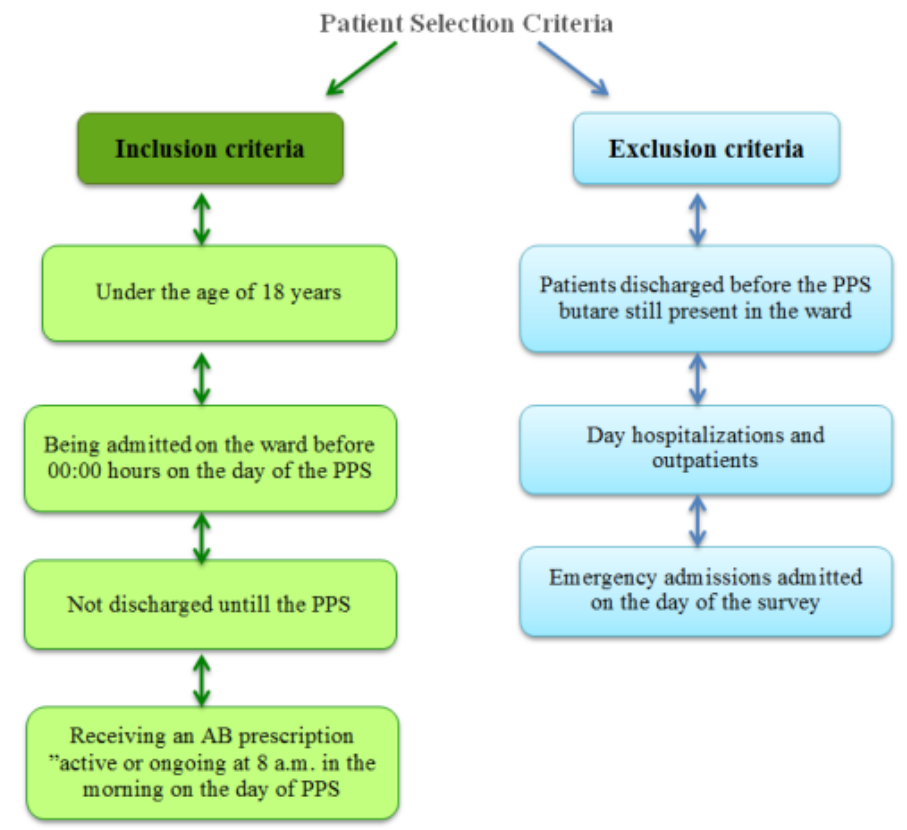

Figure 1.1. Patient selection criteria

Three data collection forms were used: Department form, Paediatric patient form and Neonatal patient form. The following data was included in the Department form: date of survey, auditor's code, type of the department mixed (e.g., therapy plus surgery) or not mixed, activity (medicine, surgery, PICU) - only for mixed departments, total number of admitted inpatients $<18$ years old at 8 a.m. on the day of PPS, total number of beds in the ward. The following data was included in the Paediatric patient form and Neonatal patient form: ward's name and activity, patient's age (gestational age of the neonates), weight (birth weight of the neonates), gender, ventilation status, underlying diagnosis, $\mathrm{AB}$ name, dose, route, times per day, reason for treatment, indication, type of treatment (empirical versus targeted treatment), notes on the reasons. See Figure 1.2. for AB selection criteria. 


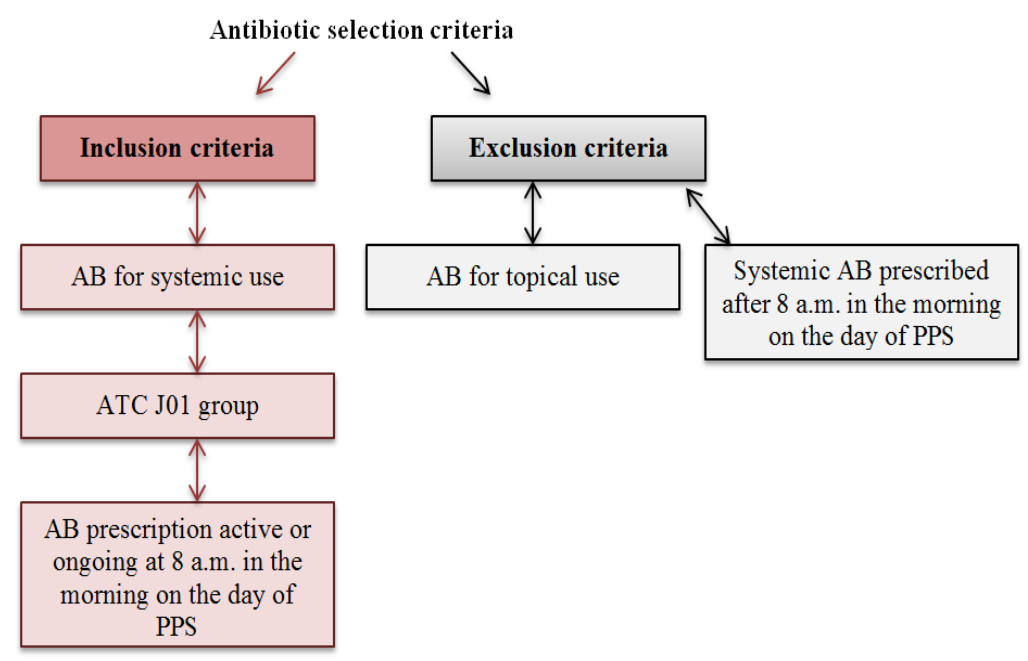

Figure 1.2. AB selection criteria

For combinations with two or more active ingredients like Cotrimoxazole the total content was recorded in the patient's form (sulfamethoxazole $200 \mathrm{mg} /$ trimethoprim $40 \mathrm{mg}$ was recorded as $240 \mathrm{mg}$ ). For combination with one active ingredient as the main antimicrobial agent, like penicillins with enzyme inhibitors, only the content of active ingredient was recorded in the patient's form (e.g., co-amoxiclav 125/31 suspension (amoxicillin $125 \mathrm{mg}$ and clavulanic acid $31 \mathrm{mg}$ as potassium salt) was recorded as prescribed $125 \mathrm{mg}$ ).

\subsubsection{Antibiotic analysis by using Defined daily dose method}

This study contains analysis of the consumption of all $\mathrm{AB}$ for systemic use (ATC J01). AB consumption data at the hospital wards were obtained from the hospital pharmacy electronic database. The amount of $\mathrm{AB}$ distributed from the pharmacy to the wards was also taken into account. The total amount of every $\mathrm{AB}$ used per year and quarter was converted in terms of grams. 
Following the ATC/DDD guideline (WHOCC, Zhang et al., 2008a) consumption rates were expressed as DDD, DDD/100 BD and DDD/100 patients. Analysis of AB annual consumption at the UCH hospital "Tornakalns" and Paediatric Surgery Clinic was completed for the period 2006-2013, but quarterly analysis on the whole hospital - for the period 2011-2013. All changes to all three matching indicators (DDD, DDD/100 BD and DDD/100 patients) were considered as important. DDD reflects the true volume of consumption, but the $\mathrm{DDD} / 100 \mathrm{BD}$ and $\mathrm{DDD} / 100$ patients - the intensity of use. The number of treated patients and the number of hospital bed-days were used to characterise intensity of patients' treatment. In addition, the analysis considered all data related the average duration of treatment. Information on bed-days, number of treated patients and average duration of the said treatment was obtained from the UCH eHealth and Statistics Department. The day of the patient's hospitalization and as well as discharge was considered as one day. Outpatients, day-stationary patients and emergency department patients were excluded from the study.

\subsubsection{Analysis of antibiotic drug utilization $(90 \% \mathrm{DU})$}

Total consumption of $\mathrm{AB}$ at the $\mathrm{UCH}$ hospital "Tornakalns" was analysed by using $90 \% \mathrm{DU}$ method. AB were ranked by amount of DDD. AB, which accounted for $90 \%$ of the total volume of use, were specifically noted (Diminga, 2013, Zhang et al., 2008b). 


\subsection{Analysis of perioperative $\mathrm{AB}$ prophylaxis and treatment in patients with most common surgical cases}

\subsubsection{Patient selection}

This study analysis patients under the age of 18 years with diagnoses code I880, K35, S42, S52, S62, S72, S82, S92 (according to ICD) hospitalized at the Paediatric Surgery Clinic. Study period: $1^{\text {st }}$ January $2001-31^{\text {st }}$ December 2003 and $1^{\text {st }}$ January $2011-31^{\text {st }}$ December 2013. A historical control group of patients with the same diagnoses treated between years 20012003 was used for the comparison. All data on patients were obtained from the patients' medical records, as well as from the UCH software "Andromeda" (patients hospitalized from $1^{\text {st }}$ January $2011-31^{\text {st }}$ December). Arrangement according to the age groups was completed by using Gerber et al. (2010) classification: under the age of 1 month, from 1 month to 1 year, from 1 year to 5 years, from 5 years to 12 years and from 12 years to 18 years. In the $\mathrm{AB}$ dosage analysis patients were arranged into two age groups: under the age of 12 years and from 12 years to 18 years.

\subsubsection{Analysis of surgical prophylaxis}

\section{Quality indicators used in the analysis of the perioperative $A B$ prophylaxis}

In order to evaluate surgical prophylaxis at the Paediatric Surgery Clinic several ECDC surgical quality indicators were used $(E C D C, 2013)$ :

$$
\begin{aligned}
& 1^{\text {st }} \text { indicator }=\frac{\text { Number of prophylaxis administered within } 60 \text { minutes before incision }}{\text { Number of all surgeries where prophylaxis was indicated and administered }} \\
& 2^{\text {nd }} \text { indicator }=\frac{\text { Number of surgeries with appropriate choice of prophylaxis }}{\text { Number of all surgeries when prophylaxis was indicated before incision }} \\
& 3^{\text {rd }} \text { indicator }=\frac{\text { Number of surgeries where prophylaxis was administered when there was an indication }}{\text { Number of all surgeries when prophylaxis was indicated }} \\
& 4^{\text {th }} \text { indicator }=\frac{\text { Number of PAP discontinued within } 24 \text { hours post-surgery }}{\text { Number of all surgeries when PAP was indicated }}
\end{aligned}
$$




\section{Surgical prophylaxis analysis criteria}

See Figure 1.3. for the timing of $\mathrm{AB}$ administration criteria.

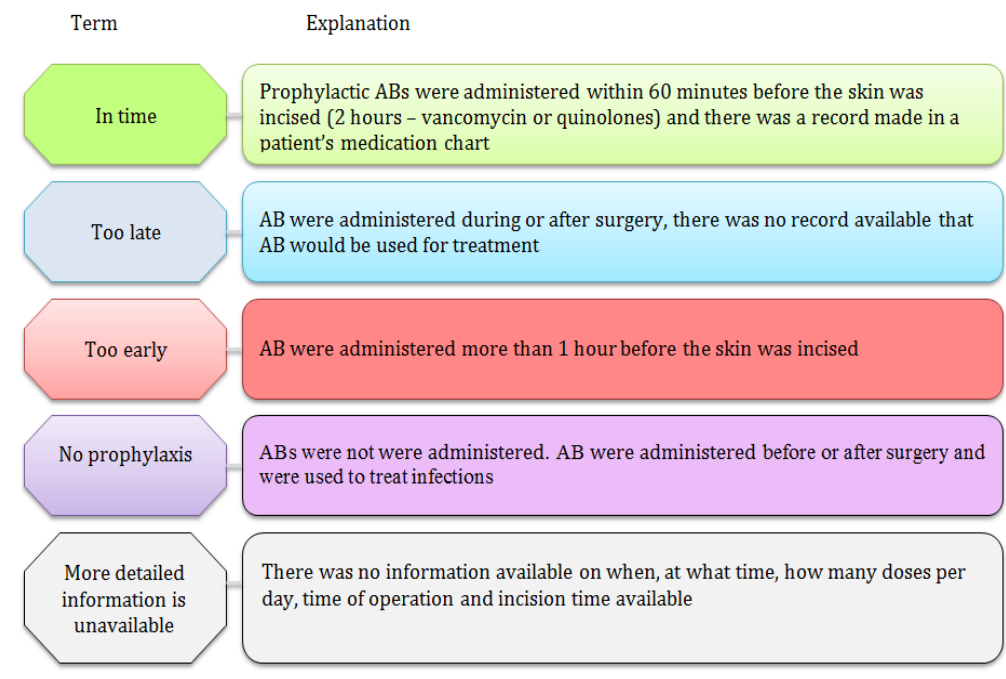

Figure 1.3. Timing of administration criteria

Duration of perioperative $\mathrm{AB}$ prophylaxis was analysed as follows: 1 dose, multiple doses within 24 hours, > 24 hours and the patient's medication chart contained no accurate data on the duration of the prophylaxis.

\subsubsection{Analysis of prescribed AB doses in the Paediatric Surgery Clinic and dosing errors in $\mathrm{AB}$ prescribed for surgical patients}

The author used four information resources for the analysis of dosing errors: the hospital Recommendations (Zavadska et al., 2013), SPC (if the brand name $\mathrm{AB}$ was registered in the SAM register (e.g., Rocephin (2010), it was used as a reference document), BNFC (BNFC, 2013) and Lexi (Taketomo, 2011). Such approach was used because the hospital's Recommendations 
approved by the hospital's General Board became effective on September 2013. Previously there were not official recommendations, which could be used as a reference for $\mathrm{AB}$ dosages. Patients whose body weight did not match the patient's medical record were excluded from the analysis. If $\mathrm{AB}$ had a dose range, e.g., cefazolin 20-30 mg/kg (Taketomo, 2011), the doses were considered as incorrect if they were lower or higher the lowest or highest dose following a particular information source.

The following SPC were used:

1) ampicillin - Pamecil (2008) and Pan-Ampicillin (2010);

2) cefazolin - Cerfazolin-IPP (2014), Cefazolin-Hospira (2014), Cefazolin-BCPP (2010) and Pan-Cefazolin (2010);

3) ceftriaxone - Rocephin (2010);

4) cefuroxime - Axetine (2011) and Cefuroxime MIP;

5) gentamicin - Gentamicin Krka (2011) and Gentamicin Sopharma (2014);

6) metronidazole - Metronidazole B. Braun (2014) and Metronidazole Fresenius (2014).

\subsubsection{Antibiotic off-label use}

All cases when $\mathrm{AB}$ was used in a way that was different from that described in the SPC, e.g., not for particular age group, indication (prophylaxis), in another dose, doses per day or route of administration were considered as off-label use (Neubert et al., 2008).

\subsection{Statistical analysis}

The statistical analysis was performed by using IBM SPSS Statistics Version 20.0 statistical software package (IBM SPSS Statistics Version 20, SPSS inc., USA) and Microsoft Excel programs. Patients' data were analysed 
by using descriptive statistical methods (percentage proportion, median, mean and standard deviation, mode, interquartile range, skewness and kurtosis). Nominal data were described as the quantity (n) and percentage with $95 \%$ CI. Categorical data were analysed with Chi-square test $(2 \times 2$ tables). Categorical (qualitative) data were also described as the quantity and percentage proportion. Data with value below 0.05 were regarded as statistically significant. Noninterrupted time series analysis was used for the analysis of the relative changes in $\mathrm{AB}$ consumption (DDD method). Relation between analysed period (year and quarter) and the dependent variable ( $\mathrm{AB}$ consumption) was analysed by means of correlation and linear regression method. Pearson' and Spearman's correlations were used to examine the relationship between two variables (Ansari et al., 2010, Dimiņa, 2013, MacKenzie et al., 2006, Teibe, 2007). The Kolmogorov-Smirnov test was used to determine, whether sample data were normally distributed. The study protocol was approved by the RSU Ethics Committee on $6^{\text {th }}$ October 2011. 


\section{RESULTS}

\subsection{Results of point prevalence surveys}

\subsubsection{Results of point prevalence surveys at the University Children's Hospital}

See Table 2.1. for patients' characteristics

Table 2.1.

UCH patients' characteristics (2011-2013)

\begin{tabular}{|c|c|c|c|c|c|c|c|}
\hline Year & \multicolumn{2}{|c|}{2011} & \multicolumn{2}{|c|}{2012} & \multicolumn{3}{|c|}{2013} \\
\hline Month & May & November & May & November & May & & vember \\
\hline Patients & $\begin{array}{c}\mathrm{N}(\%) \\
{[95 \% \mathrm{CI}]}\end{array}$ & $\begin{array}{c}\mathrm{N}(\%) \\
{[95 \% \mathrm{CI}]}\end{array}$ & $\begin{array}{c}\mathbf{N}(\%) \\
{[95 \% \mathrm{CI}]}\end{array}$ & $\begin{array}{c}\mathrm{N}(\%) \\
{[95 \% \mathrm{CI}]}\end{array}$ & $\begin{array}{c}\mathrm{N}(\%) \\
{[95 \% \mathrm{CI}]}\end{array}$ & \multicolumn{2}{|c|}{$\begin{array}{c}\mathbf{N}(\%) \\
{[95 \% \mathrm{CI}]}\end{array}$} \\
\hline $\begin{array}{l}\text { Total } \\
\text { number }\end{array}$ & 418 & 424 & 395 & 358 & 335 & \multicolumn{2}{|c|}{320} \\
\hline Boys & $\begin{array}{l}230(55.0) \\
{[50.2-59.8]}\end{array}$ & $\begin{array}{c}225(53.1) \\
{[48.4-57.9]}\end{array}$ & $\begin{array}{l}215(54.4) \\
{[49.5-59.3]}\end{array}$ & $\begin{array}{c}196(54.7) \\
{[49.5-59.9]}\end{array}$ & $\begin{array}{r}178(53.1) \\
{[47.8-58.4]}\end{array}$ & \multicolumn{2}{|c|}{$\begin{array}{r}159(49.7) \\
{[44.2-55.2]}\end{array}$} \\
\hline Girls & $\begin{array}{c}188(45.0) \\
{[40.2-49,8]}\end{array}$ & $\begin{array}{c}199(46.9) \\
{[42.2-51.7]}\end{array}$ & $\begin{array}{r}180(45.6) \\
{[40.7-50.5]}\end{array}$ & $\begin{array}{c}162(45.3) \\
{[40.1-50.5]}\end{array}$ & $\begin{array}{c}157(46.9) \\
{[41.6-52.2]}\end{array}$ & \multicolumn{2}{|c|}{$\begin{array}{r}161(50.3) \\
{[44.8-55.8]}\end{array}$} \\
\hline $\begin{array}{l}\text { Patients } \\
\text { on } A B\end{array}$ & $\begin{array}{c}125(29.9) \\
{[25.5-34.3]}\end{array}$ & $\begin{array}{c}159(37.5) \\
{[32.9-42.1]}\end{array}$ & $\begin{array}{l}128(32.4) \\
{[27.8-37.0]}\end{array}$ & $\begin{array}{c}130(36.3) \\
{[31.3-41.3]}\end{array}$ & $\begin{array}{c}88(26.3) \\
{[21.6-31.0]}\end{array}$ & \multicolumn{2}{|c|}{$\begin{array}{c}111(34.7) \\
{[29.5-39.9]}\end{array}$} \\
\hline $\begin{array}{l}\text { Chi- } \\
\text { square } \\
\text { test } \\
\end{array}$ & \multicolumn{2}{|c|}{$\mathrm{p}=0.101$} & \multicolumn{2}{|c|}{$\mathrm{p}=0.430$} & \multicolumn{3}{|c|}{$\mathrm{p}=0.087$} \\
\hline $\begin{array}{l}\text { Median } \\
\text { age } \\
\text { (months) }\end{array}$ & 33 & 41 & 33 & 48 & 43 & & 41 \\
\hline \multicolumn{8}{|l|}{ Gender: } \\
\hline Male & $\begin{array}{c}63(50.4) \\
{[41.6-} \\
59.2] \\
\end{array}$ & $\begin{array}{c}90(56.6) \\
{[48.9-63.3]}\end{array}$ & $\begin{array}{r}59(46.1) \\
{[37.5-54.7]}\end{array}$ & $\begin{array}{r}74(56.9) \\
{[48.4-65.4]}\end{array}$ & $\begin{array}{r}47(5 \\
{[43.0-6}\end{array}$ & & $\begin{array}{c}57(51.4) \\
{[42.1-} \\
60.7]\end{array}$ \\
\hline Female & $\begin{array}{c}62(49.6) \\
{[40.8-} \\
58.4] \\
\end{array}$ & $\begin{array}{r}69(43.4) \\
{[35.7-51.1]}\end{array}$ & $\begin{array}{r}69(53.9) \\
{[45.3-62.5]}\end{array}$ & $\begin{array}{c}56(43.1) \\
{[34.6-51.6]}\end{array}$ & $\begin{array}{r}41(46 \\
{[36.2-5}\end{array}$ & & $\begin{array}{c}54(48.6) \\
{[39.3-} \\
57.9] \\
\end{array}$ \\
\hline $\begin{array}{l}\text { Chi- } \\
\text { square } \\
\text { test }\end{array}$ & $\mathrm{p}=0.215$ & $\mathrm{p}=0.258$ & $\mathrm{p}<0.05$ & $\mathrm{p}=0.532$ & $\mathrm{p}=0$ & & $\begin{array}{c}p= \\
0.664\end{array}$ \\
\hline \multicolumn{8}{|c|}{ Age groups: } \\
\hline $\begin{array}{l}0-<1 \\
\text { month }\end{array}$ & $\begin{array}{c}20 \\
(16.0)\end{array}$ & 19 (12.0) & $10(7.8)$ & $12(9.2)$ & $10(11$ & & $\begin{array}{c}19 \\
(17.1)\end{array}$ \\
\hline $\begin{array}{l}\geq 1 \text { month } \\
-<1 \text { year }\end{array}$ & $\begin{array}{c}14 \\
(11.2)\end{array}$ & $24(15.1)$ & $27(21.1)$ & $21(16.2)$ & $13(14$ & & $\begin{array}{c}20 \\
(18.0)\end{array}$ \\
\hline $\begin{array}{l}\geq 1-<5 \\
\text { years }\end{array}$ & $\begin{array}{c}52 \\
(41.6)\end{array}$ & $54(34.0)$ & $33(25.8)$ & $36(27.7)$ & $32(36$ & & $\begin{array}{c}24 \\
(21.6)\end{array}$ \\
\hline $\begin{array}{l}\geq 5-<12 \\
\text { years }\end{array}$ & $\begin{array}{c}27 \\
(21.6)\end{array}$ & $33(20.8)$ & $29(2.7)$ & $35(26.9)$ & $14(15$ & & $\begin{array}{c}27 \\
(24.3)\end{array}$ \\
\hline $\begin{array}{l}\geq 12-< \\
18 \text { years }\end{array}$ & $12(9.6)$ & $29(18.2)$ & $29(22.7)$ & $26(19.5)$ & $19(20$ & & $\begin{array}{c}21 \\
(18.9)\end{array}$ \\
\hline
\end{tabular}


Any of PPS did not have normal distribution of patients (KolmogorovSmirnov test).

\section{Antibiotic groups used in point prevalence surveys}

The most commonly used AB group in all PPS, except on May and November 2011, was other $\beta$-lactam AB (J01D) (See Figure 2.1.).

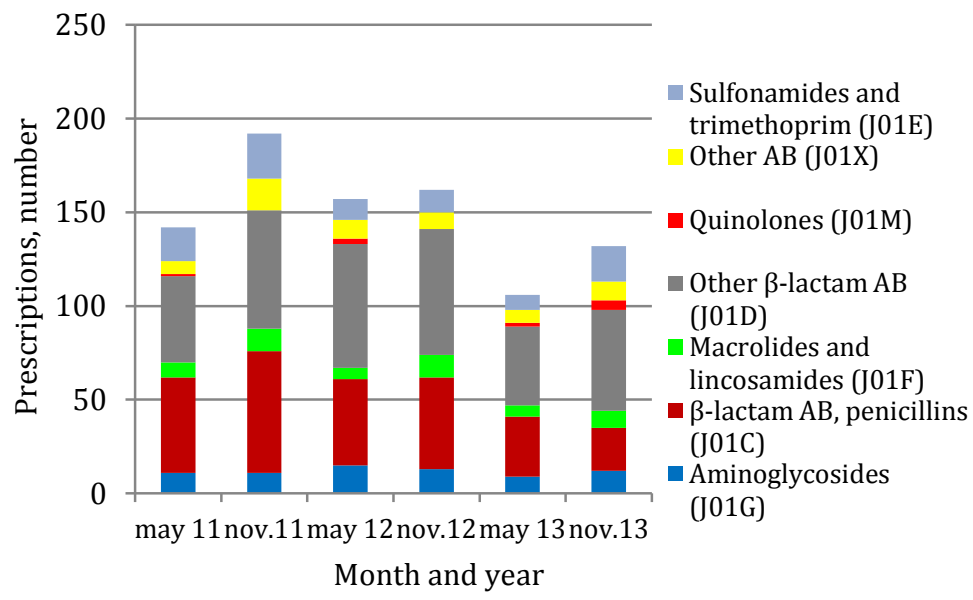

Figure 2.1. AB groups used during PPS in 2011-2013

In $\beta$-lactam penicillin (J01C) group the commonly used $\mathrm{AB}$ were penicillins of the extended-spectrum (J01CA): from 49.0\% (CI 41.3-56.7) of all $\beta$-lactam AB in the PPS in November of 2012 up to $70.6 \%$ (CI 63.1-78.1) in May 2011 (average 58.7\%: 62.3\% in May's PPS and 55.2\% in November's PPS). The Chi-squared test showed that statistically seasonal changes (May November) did not have significant influence on the use of the extendedspectrum penicillins $(\mathrm{p}>0.05)$. In cephalosporin group the most commonly used $\mathrm{AB}$ were the $3^{\text {rd }}$ generation cephalosporins: from $54.5 \%$ (CI 46.0-63.0) in 
the PPS in November 2013 up to 72.6\% (CI 66.3-78.9) in November of 2011 (average 62.7\%: 63.0\% in May's PPS and 62.4\% in November's PPS) (See Figure 2.2.).

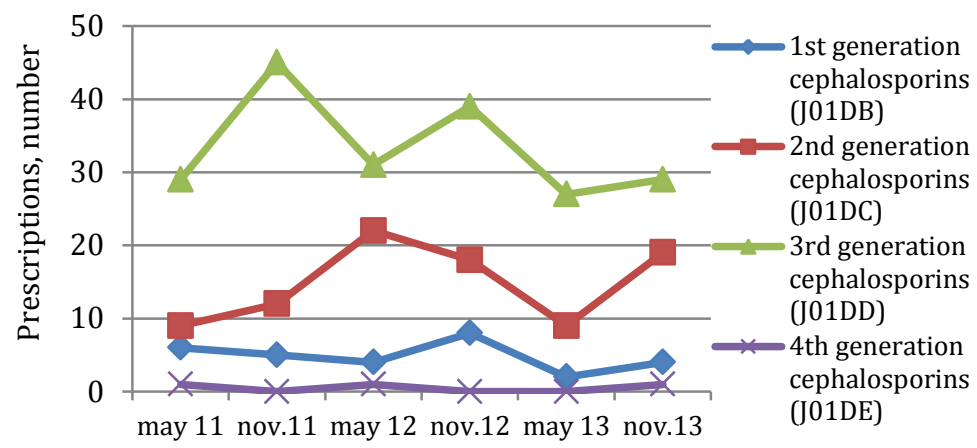

Month and year

Figure 2.2. Cephalosporin consumption in PPS during the period of 2011-2013

\section{A consumption of particular antibiotics in point prevalence surveys during the period of 2011-2013}

There were $21 \mathrm{AB}$ used in May 2011 and $20 \mathrm{AB}$ - in November 2011, 23 AB - in May 2012 and 20 AB - November 2012, and 21 AB in both May and November 2013. Ampicillin was the most commonly used AB in May 2011: 25 (17.6\%; CI 11.3-23.9) prescriptions, but in November 2013 ampicillin shared the $7^{\text {th }}-9^{\text {th }}$ place with gentamicin and amikacin: $6(4.5 \%$; CI 1.0-8.0) prescriptions. Ceftriaxone was the fifth most frequently used $\mathrm{AB}$ in May 2011: 12 (8.5\%; CI 3.9-13.1) prescriptions, but in November 2013 it became the most often used AB: 23 (17.4\%; CI 10.9-23.9) prescriptions. 


\section{Route of administration}

There were only IV and $\mathrm{O}$ route of administration. IV route of administration dominated in all PPS. The lowest number of IV prescriptions was registered in November $2013-75.8 \%$, but the highest $-86.2 \%$ in May 2013 (See Figure 2.3.).

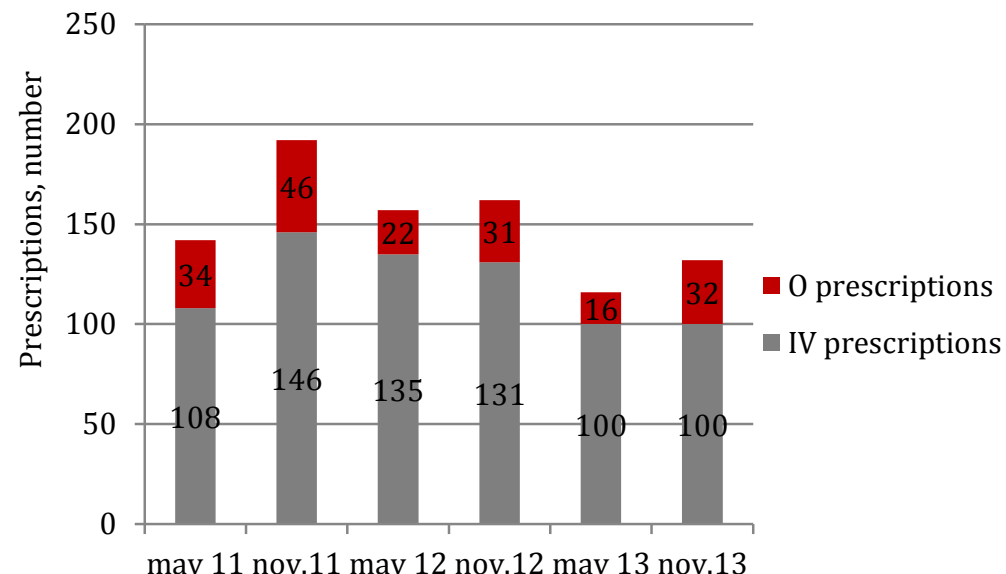

Month and year

Figure 2.3. Number of IV and O prescriptions in PPS during the period of 2011-2013

\section{Surgical prophylaxis - paediatric patients}

All PPS had low number of surgical prophylaxis prescriptions: from 4 (4.5\%, CI 0.2-8.8) prescriptions in May 2013 to 13 (9.1\%, CI 4.4-13.8) in November 2012. Most patients received prophylactic AB for more than one day: from $50.0 \%$ (4 prescriptions) in November 2011 to 100\% (7 prescriptions) in May 2011 and 100\% (12 prescriptions) in November 2012. In total there were $9 \mathrm{AB}$ used in PPS. The most commonly prescribed $\mathrm{AB}$ was cefuroxime: $20(42.5 \%)$ prescriptions in all PPS. The second most frequently used AB was ceftriaxone - $12(25.5 \%)$ prescriptions. All $\mathrm{AB}$ were prescribed in 
monotherapy, except for one ampicillin and gentamicin combination in May 2011.

\subsubsection{Antibiotic consumption at Latvian hospitals}

In November 2012 the PPS was conducted as a part of the ARPEC study. Nine hospitals from Latvia participated in this PPS. Five hundred forty nine patients were included in the study. AB was received by $192(35.0 \%$, CI 31.0-39.0) patients: 167 (87.0\%, CI 82.2-91.8) children and adolescent and 25 (13.0\%, CI 8.2-17.8) neonates. Patients hospitalized at the UCH hospitals "Torņakalns" and "Gaiļezers" represented $67.0 \%$ of all patients receiving AB.

The highest number of patients was in the group of 5-12 years old - $53(28.0 \%$, CI 21.3-33.9): 33 (17.1\%, CI 11.8-22.4) boys and 20 (10.4\%, CI 6.1-14.7) girls.

\section{Used antibiotics}

The most commonly used $\mathrm{AB}$ group in paediatric patients was other $\beta$ lactam $\mathrm{AB}$ (J01D) - 101 (50.8\%; CI 43.9-57.8) prescription, but the second most commonly used $\mathrm{AB}$ group was $\beta$-lactam $\mathrm{AB}$, penicillins $(\mathrm{J} 01 \mathrm{C})-52$ (26.1\%; CI 20.0-32.2) prescriptions. Ceftriaxone was the most commonly prescribed $\mathrm{AB}-41$ (20.6\%; CI 15.0-26.2) prescription.

\subsection{Antibiotic consumption by using defined daily dosage method}

\subsubsection{Antibiotic consumption in the hospital}

At the UCH hospital "Tornakalns" the number of treated patients decreased from 26055 patients in 2006 to 22211 in $2013(\mathrm{r}=-0.89, \mathrm{p}<0.05)$, and the number of bed-days - from 149125 in 2006 to $92575(\mathrm{r}=-0.99, \mathrm{p}<$ 
0.05). The average duration of treatment decreased from 5.7 days in 2006 to 4.2 days in 2013. In total there were $91 \mathrm{AB}$ formulations used during the period of 2006-2013: 44 (48.4\%) IV and 47 (51.6\%) O formulations (Figure 2.4.).

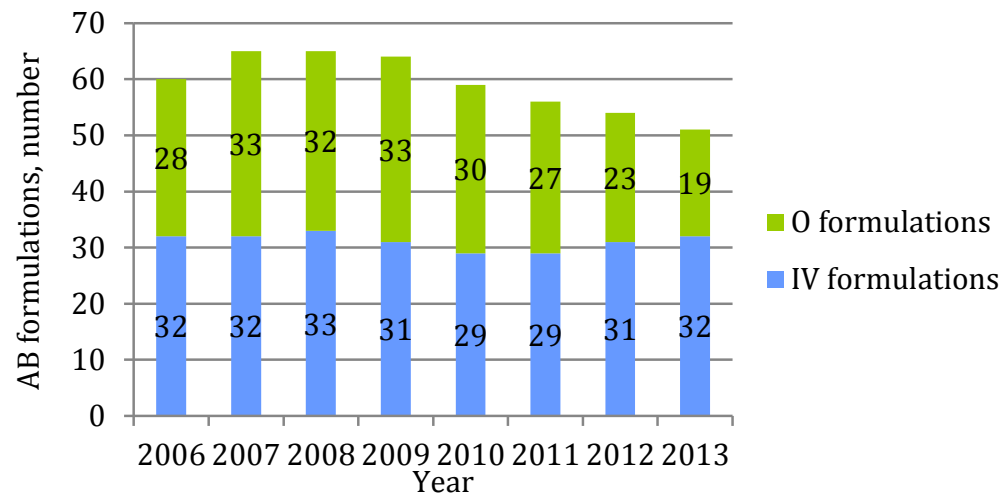

Figure 2.4. Number of IV and $\mathrm{O}$ formulations at the UCH hospital "Torņakalns" in 2006-2013

The total $\mathrm{AB}$ consumption (in DDD) decreased from $58847 \mathrm{DDD}$ in 2006 to 45406 DDD in $2013(\mathrm{r}=-0.77, \mathrm{p}<0.05)$. The total number of $\mathrm{AB}$ substances equalled 29 in 2012 and 36 in 2006 and 2007 respectively. There was a strong positive correlation (Spearman's rank correlation coefficient $r_{s}=$ 0.92 ) between available active substances and $A B$ consumption in DDD/100 $\mathrm{BD})$. The total $\mathrm{AB}$ consumption in $\mathrm{DDD} / 100 \mathrm{BD}$ increased by $25.1 \%$ : from $39.5 \mathrm{DDD} / 100 \mathrm{BD}$ in 2006 till 49.4 DDD/100 BD in 2013. AB consumption (DDD/100 patients) slightly decreased: from 225.9 DDD/100 patients in 2006 till 204.4 DDD/100 patients in 2013 but it was not statistically significant ( $\mathrm{p}=$ $0.08)$. 


\section{Antibiotic seasonal consumption}

Hospital showed different total results of $\mathrm{AB}$ consumption for the different quarters (2011-2013). These differences were not critical (See Figure 2.5.).

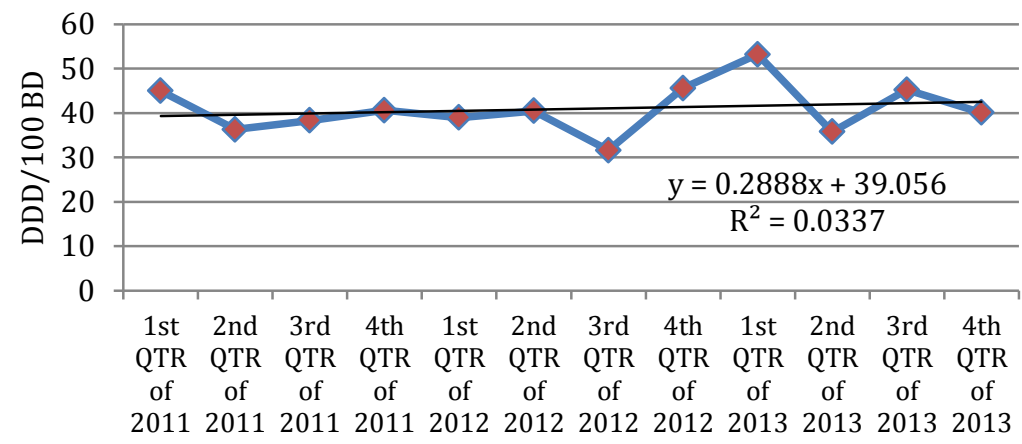

\section{QTR and year}

Figure 2.5. Total AB consumption at the UCH during different quarters for the period of 2011-2013 (DDD/100 BD)

In 2011 and 2013 the highest $\mathrm{AB}$ consumption by indicators (DDD, $\mathrm{DDD} / 100 \mathrm{BD}$ and $\mathrm{DDD} / 100$ patients) was registered during the $1^{\text {st }}$ quarter. In 2013 the second highest consumption was registered in summer, although the number of treated patients (4858) and bed-days (26658) was the lowest if to be compared with other quarters in 2013. DDD/100 patients: $53.2-$ in the $1^{\text {st }}$ quarter, 35.8 - in the $2^{\text {nd }}$ quarter 45.2 - in the $3^{\text {rd }}$ quarter and $40.1-$ in the $4^{\text {th }}$ quarter. While analysing the consumption of different cephalosporin groups (DDD/100 BD), it was established that the $3^{\text {rd }}$ generation cephalosporins had the highest percentage of consumption in all quarters: from 48.6\% (6.9 $\mathrm{DDD} / 100 \mathrm{BD})$ in the $1^{\text {st }}$ quarter of 2013 to $67.8 \%(6,4 \mathrm{DDD} / 100 \mathrm{BD})$ in the $1^{\text {st }}$ quarter of 2011. 


\section{Antibiotics used at the UCH "Tornakalns"}

During the period of 2006-2013 the most commonly used AB groups were $\beta$-lactam $\mathrm{AB}$, penicillins (J01C) and other $\beta$-lactam $\mathrm{AB}$ (J01D), which combined accounted for $75.5 \%$ of the total $\mathrm{AB}$ consumption (DDD) registered in 2006 and $73.6 \%$ in 2013. A similar trend was also observed in DDD/100 BD (See Figure 2.6.) - from $73.5 \%$ of the total AB consumption in 2013 to $77.7 \%$ in 2010 and in DDD/100 patients - from $73.6 \%$ in 2013 to $77.8 \%$ in 2010.

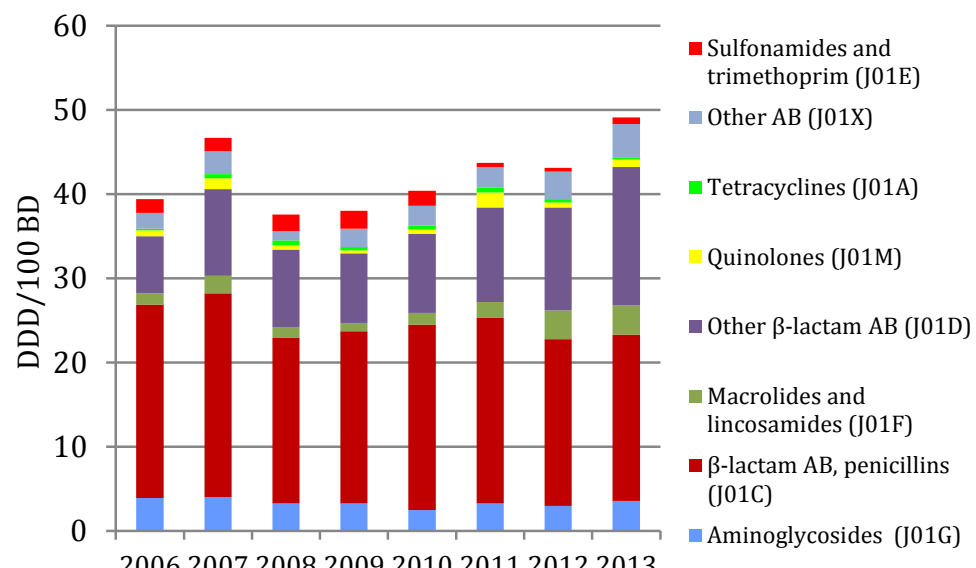

20062007200820092010201120122013

Year

Figure 2.6. AB groups used at the UCH hospital „Tornakalns" during the period of 2006-2013 (DDD/100 BD)

\section{B-lactam group antibiotic (J01C) consumption}

Total $\beta$-lactam AB consumption (in DDD, DDD/100 BD and DDD/100 patients) decreased almost twice (See Table 2.2.). 
Table 2.2.

J01C group AB consumption at the UCH hospital "Tornakalns" during the period of 2006-2013

\begin{tabular}{|l|c|c|c|c|c|c|c|c|}
\hline \multicolumn{1}{|c|}{ Year } & $\mathbf{2 0 0 6}$ & $\mathbf{2 0 0 7}$ & $\mathbf{2 0 0 8}$ & $\mathbf{2 0 0 9}$ & $\mathbf{2 0 1 0}$ & $\mathbf{2 0 1 1}$ & $\mathbf{2 0 1 2}$ & $\mathbf{2 0 1 3}$ \\
\hline DDD & 34279 & 35425 & 26830 & 25454 & 25999 & 25647 & 20212 & 18194 \\
\hline $\begin{array}{l}\text { DDD/100 } \\
\text { BD }\end{array}$ & 23.0 & 24.2 & 19.7 & 20.4 & 22.0 & 22.0 & 19.8 & 19.7 \\
\hline $\begin{array}{l}\text { DDD/100 } \\
\text { patients }\end{array}$ & 131.6 & 135.7 & 111.8 & 106.7 & 110.7 & 90.1 & 87.9 & 81.9 \\
\hline
\end{tabular}

\section{Other $\beta$-lactam antibiotic (J01D) consumption}

Statistically both the total other $\beta$-lactam $\mathrm{AB}$ and cephalosporin consumption increased significantly only for DDD/100 BD $(r=0.84, p<0.05)$ and $(\mathrm{r}=0.85, \mathrm{p}<0.05)$. Statistically the $1^{\text {st }}$ generation cephalosporin consumption decreased significantly in respect of all three indicators (DDD/100 BD $r=-0.82, p<0.05)$, but the $2^{\text {nd }}$ generation, and especially $3^{\text {rd }}$ generation cephalosporin consumption, statistically significantly increased: $(r=0.90$, $\mathrm{p}<0.05)$ and $(\mathrm{r}=0.92, \mathrm{p}<0.05)$ respectively. There was no correlation between the decrease of penicillins' consumption and the increase of cephalosporins' consumption neither in DDD $(\mathrm{r}=-0.22, \mathrm{p}=0.60)$ nor $\mathrm{DDD} / 100 \mathrm{BD}(\mathrm{r}=-0.40, \mathrm{p}=0.32)$. Ceftriaxone consumption increased in respect to all three indicators: DDD - 3 times (from 1940 in 2006 - 6243 in 2013), DDD/100 BD - 5 times (from 1.3-6.7), but DDD/100 patients - almost 4 times (from 7.4-28.1).

\section{Antibiotic group (J01A, J01E, J01F, J01G, J01M and J01X) consumption}

Statistically none of these groups had significant consumption growth or reduction. 


\subsubsection{Antibiotic consumption in hospital wards}

In $2006 \mathrm{AB}$ consumption at the Paediatric Surgery Clinic equalled $28.0 \%$ (16482 DDD) of the total consumption and in PICU - 3.4\% (2019 DDD), but in $2013-22.8 \%$ (10369 DDD) and 3.9\% (1761 DDD) respectively. In 2013 the intensity of $\mathrm{AB}$ usage (DDD/100 BD) was the highest in oncohematology (92.5 DDD/100 BD), PICU (84.3 DDD/100 BD) and General Paediatric ward of the hospital "Tornakalns" (82.2 DDD/100 BD).

\subsubsection{Antibiotic consumption at the Paediatric Surgery Clinic}

Total $\mathrm{AB}$ consumption for both DDD $(\mathrm{r}=-0.80, \mathrm{p}<0.05)$ and $\mathrm{DDD} / 100(\mathrm{r}=-0.76, \mathrm{p}<0.05)$ decreased. It also decreased for DDD/100 BD, but these changes were not statistically significant $(p=0.16)$. The most commonly used $\mathrm{AB}$ groups were $\beta$-lactam $\mathrm{AB}$, penicillins (J01C) and other Blactam AB (J01D). These two groups together equalled $76.1 \%$ of the total $\mathrm{AB}$ consumption (DDD) in 2011 to $83.3 \%$ in 2007. Similar tendency was identified for $\mathrm{DDD} / 100 \mathrm{BD}$ - from $76.2 \%$ of the total $\mathrm{AB}$ consumption in 2011 to $83.7 \%$ in 2007. The consumption of the $1^{\text {st }}$ generation cephalosporins decreased from $807(31.0 \%)$ DDD in 2006 to 770 (21.0\%) DDD of the total cephalosporin consumption in 2013 , but the consumption of the $3^{\text {rd }}$ generation cephalosporins increased from 685 (26.0\%) DDD in 2006 to 1547 (43.0\%) in 2013. There was no correlation between the decrease of the $1^{\text {st }}$ generation consumption and the increase of the $3^{\text {rd }}$ generation consumption $(r=-0.13, p>0.05)$. 


\subsection{Antibiotic consumption $90 \% \mathrm{DU}$ analysis}

During the period of 2006-2013 the total number of used AB ranged from $36 \mathrm{AB}$ (in 2006) to $30 \mathrm{AB}$ (in 2012). Ninety percent of all used $\mathrm{AB}$ equalled 13.8 $\mathrm{AB}$ in average. The lowest number of $90 \% \mathrm{DU} \mathrm{AB}$ was registered in $2007-38.9 \%$, but the highest $-45.2 \%$ in 2011. Starting from 2008, amoxicillin (J01CA04) was the most commonly used $\mathrm{AB}$ at the hospital. During the studied period it was also the only $\mathrm{AB}$ that was among five most frequently used $\mathrm{AB}$ (See Figure 2.7.). Amoxicillin consumption increased from $12.3 \%$ in 2006 to $23.1 \%$ in 2013. Although ampicillin (J01CA01) was among $90 \% \mathrm{DU} \mathrm{AB}$, during the studied period the ampicillin usage decreased significantly: from $20.5 \%$ of the total consumption in 2006 to $5.5 \%$ in 2013. The usage of ceftriaxone (J01DD04) increased from 3.3\% in 2006 to $13.8 \%$ in 2013, and starting from 2010, it became the second most frequently used AB.
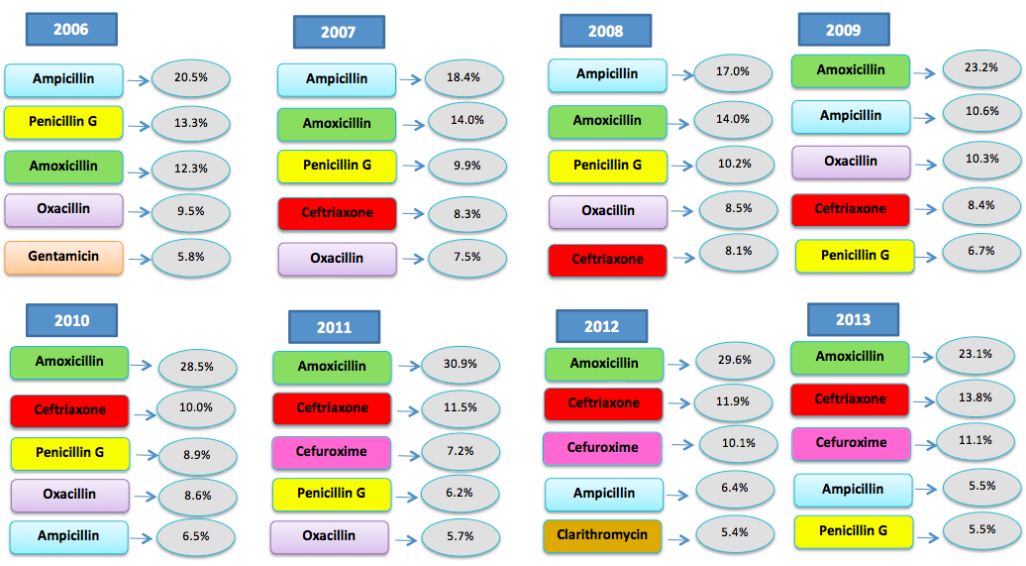

Figure 2.7. Five most commonly used $A B$ at the UCH hospital "Tornakalns" during the period of 2006-2013 (90\%DU) 


\subsection{Acute appendicitis: the patients' characteristics and analysis of the antibiotic usage}

\subsubsection{The patients and surgeries' characteristics and analysis of prophylaxis and treatment}

Table 2.3. shows the patients' characteristics included into the study. During the period of 2011-2013 the highest number of patients was patients under the age of 12 years, but in 2001-2003 - at the age of 12-18 years. In 2013 surgery was not performed in 29 (5.6\%) patients: 10 (34.5\%) girls and 19 (65.5\%) boys, but in 2001-2003 the surgery was not performed in $10(1.3 \%)$ patients: 7 (70.0\%) girls and $3(30.0 \%)$ boys.

Table 2.3.

Demographic characteristics on the patients with acute appendicitis (20012003 and 2011-2013)

\begin{tabular}{|c|c|c|c|c|}
\hline Year & \multicolumn{2}{|c|}{ 2011-2013 } & \multicolumn{2}{|c|}{ 2001-2003 } \\
\hline Patients & $\begin{array}{c}\text { Total N } \\
(\%)[95 \% \mathrm{CI}]\end{array}$ & $\begin{array}{c}\text { Had surgery } \\
(\%)[95 \% \mathrm{CI}]\end{array}$ & $\begin{array}{c}\text { Total N } \\
(\%)[95 \% \mathrm{CI}]\end{array}$ & $\begin{array}{l}\text { Had surgery } \\
(\%)[95 \% \mathrm{CI}]\end{array}$ \\
\hline Total number & 520 & $\begin{array}{c}491(94.4) \\
{[92.4-96.4]} \\
\end{array}$ & 773 & $\begin{array}{c}763(98.7) \\
{[97.9-99.5]} \\
\end{array}$ \\
\hline Boys & $\begin{array}{c}311(59.8) \\
{[55.6-64.0]}\end{array}$ & $\begin{array}{c}292(59.5) \\
{[55.2-63.8]}\end{array}$ & $\begin{array}{c}449(58.1) \\
{[54.6-61.6]}\end{array}$ & $\begin{array}{c}446(58.5) \\
{[55.0-62.0]}\end{array}$ \\
\hline Girls & $\begin{array}{c}209(40.2) \\
{[36.0-44.4]}\end{array}$ & $\begin{array}{c}199(40.5) \\
{[36.2-44.8]}\end{array}$ & $\begin{array}{c}324(41.9) \\
{[38.4-45.4]}\end{array}$ & $\begin{array}{c}317(41.5) \\
{[38.0-45.0]}\end{array}$ \\
\hline $\begin{array}{l}\text { Mean age (years } \\
\pm \text { SD) }\end{array}$ & $11.4 \pm 4.0$ & $11.4 \pm 4.0$ & $11.5 \pm 3.7$ & $11.6 \pm 3.7$ \\
\hline $\begin{array}{l}\text { Median age } \\
\text { (years) }\end{array}$ & 11.5 & 11.4 & 12.1 & 12.2 \\
\hline
\end{tabular}

The number of patients, who had surgery and to whom $\mathrm{AB}$ was or was not administered in 2011-2013 and 2001-2003 is presented in Figure 2.8. Statistically there was significant difference between patients, who had surgery and to whom $\mathrm{AB}$ was or was not administered in 2011-2013 and 2001-2003 (Chi-squared test, $\mathrm{p}<0.05)$. Perforative appendicitis had $79(15.2 \%)$ patients in 2011-2013 and $110(14.2 \%)$ patients in 2001-2003. Surgery was performed in all these patients. 


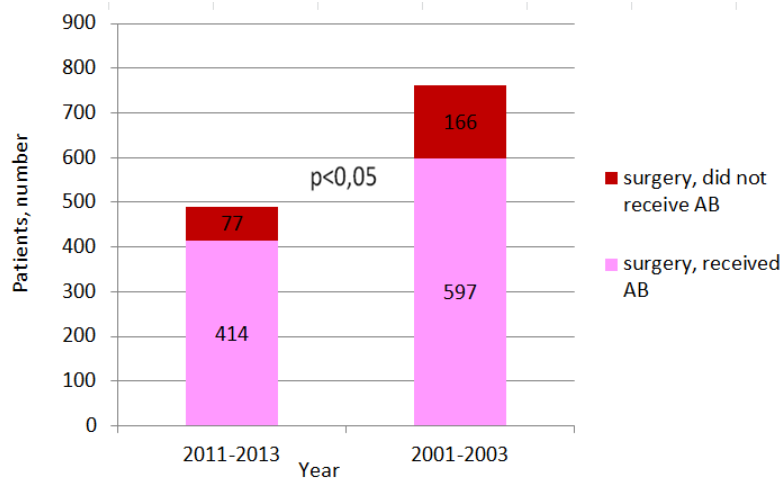

Figure 2.8. Patients with acute appendicitis, who had a surgery and to whom AB was or was not administered during the period of 2001-2003 and 2011-2013

In 2011-2013 283 (68.4\%, CI 63.9-72.9) patients did not receive $\mathrm{AB}$ prophylaxis, 99 (23.9\%, CI 19.8-28.0) received but in 32 (7.7\%, CI 5.1-10.3) cases there was no detailed information available whether or not the $\mathrm{AB}$ usage was initiated before the surgery. In 2001-2003 354 (59.3\%, CI 55.4-63.2) patients did not receive AB prophylaxis, 221 (37.0\%, CI 33.1-40.9) received, but in 22 (3.7\% CI 2.2-5.2) cases there was no detailed information available. Statistically there was significant difference between patients, who received or did not receive AB prophylaxis in 2011-2013 and 2001-2003 (Chi-squared test, p < 0.05). In 2011-2013 $36(36.4 \%)$ patients had timely prophylaxis, but in 2001-2003 - 25 (11.3\%) patients. Reason in notes was not written in 174/414 (42.0\%) patient medical charts for those patients who had surgery in 20112013. In 2001-2003 such patient medical charts were 392/597 (65.7\%). In 2001-2003 44.3\% or 58 patients with diagnosis acute phlegmanous or catarrhal appendicitis received AB for longer than 24 hours but in 2011-2013-55.8\% or 29 patients. The indication of $\mathrm{AB}$ administration time was not written in $60.2 \%$ or 133 patients' records in 2001-2003 and in $85.9 \%$ or 85 records in 20112013. Four the most commonly used AB are indicated in Table 2.4. 
Table 2.4.

Four most commonly prescribed AB for surgical prophylaxis (2011-2013 and 2001-2003)

\begin{tabular}{|c|c|c|c|c|}
\hline Year & \multicolumn{2}{|c|}{ 2011-2013 } & \multicolumn{2}{|c|}{$2001-2003$} \\
\hline $\begin{array}{l}\text { Total number of } \\
\text { prescriptions }\end{array}$ & \multicolumn{2}{|c|}{165} & \multicolumn{2}{|c|}{391} \\
\hline Antibiotics & $\begin{array}{l}\text { Mono } \\
\text { therapy } \\
\mathrm{N}(\%)\end{array}$ & $\begin{array}{c}\text { Combination } \\
\text { therapy } \\
\mathrm{N}(\%) \\
\end{array}$ & $\begin{array}{l}\text { Mono } \\
\text { therapy } \\
\mathrm{N}(\%)\end{array}$ & $\begin{array}{c}\text { Combination } \\
\text { therapy } \\
\mathrm{N}(\%) \\
\end{array}$ \\
\hline Ampicillin & $12(7.3)$ & $49(29.7)$ & 45 (11.5) & $141(36.1)$ \\
\hline Gentamicin & 0 & $47(28.5)$ & 0 & $149(38.1)$ \\
\hline Metronidazole & 0 & $18(10.9)$ & 0 & $21(5.4)$ \\
\hline Ceftriaxone & $6(3.6)$ & $13(7.9)$ & $4(1.0)$ & $3(0.8)$ \\
\hline
\end{tabular}

\subsubsection{Analysis of the dosages of the most commonly used antibiotics}

The Summary contains analysis of ampicillin and gentamicin dosages.

\section{Ampicillin}

According to BNFC in 2011-2013 ampicillin doses were correct in $18 / 61$ (29.5\%) prescriptions, but too high in 43 (70.5\%) prescriptions. According to Lexi and SPC recommendations, doses were correct in 40 (65.6\%) prescriptions, but too low in $21(34.4 \%)$ prescriptions. According to BNFC in 2001-2003 doses were correct in 59 (32.8\%) prescriptions, too low in $3(1.7 \%)$, but too high in $118(65.6 \%)$ prescriptions. According to Lexi and SPC, doses were correct in $128(71.1 \%)$ prescriptions, but too low in 52 (28.9\%) prescriptions.

\section{Gentamicin}

According to SPC in 2011-2013 doses were too low in 30/47 (63.8\%) prescriptions and in 2001-2003 they were too low in 82 (57.7\%) prescriptions. 
According to BNFC and Lexi recommendations, gentamicin doses were too low in all prescriptions.

\subsubsection{Antibiotic off-label use}

\section{Antibiotic prescriptions outside the indication and patient's age}

The Summary contains analysis of ampicillin and gentamicin prescriptions only.

\section{Ampicillin}

All prescriptions: 61 in 2011-2013 and 180 in 2001-2003 were outside of the indication, prophylaxis listed in the SPC.

\section{Gentamicin}

According to Gentamicin Sopharma (2014) SPC the usage outside the indication (prophylaxis) was in 47 cases in 2011-2013 and in 142 cases in 2001-2003.

\section{Antibiotic doses that do not correspond to the Summary of Product Characteristics}

The Summary does analyse ampicillin, gentamicin and metronidazole off-label doses. AB doses were not prescribed in accordance with SPC in $65 / 126(51.6 \%)$ prescriptions in 2011-2013 and in 143/343 (41.7\%) prescriptions in 2001-2003. 
2.5. Mesadenitis: the patients' characteristics and analysis of the antibiotic usage

\subsubsection{Patients' characteristics and treatment analysis}

Patients' demographic characteristics are presented in Table 2.5.

Table 2.5.

Patients with mesadenitis demographic characteristics (2001-2003 and 2011-2013)

\begin{tabular}{|c|c|c|c|c|c|c|}
\hline Year & \multicolumn{3}{|c|}{ 2011-2013 } & \multicolumn{3}{|c|}{ 2001-2003 } \\
\hline Patients & \multicolumn{3}{|c|}{$\mathbf{N}(\%)[95 \% \mathrm{CI}]$} & \multicolumn{3}{|c|}{$\mathbf{N}(\%)[95 \% \mathrm{CI}]$} \\
\hline Boys & \multicolumn{3}{|c|}{$87(48.1)[40.8-55.4]$} & \multicolumn{3}{|c|}{$192(48.1)[43.2-53.0]$} \\
\hline Girls & \multicolumn{3}{|c|}{$94(51.9)[44,6-59.2]$} & \multicolumn{3}{|c|}{$207(51.9)[47.0-56.8]$} \\
\hline $\begin{array}{c}\text { Mean age (years } \\
\pm \mathrm{SD})\end{array}$ & \multicolumn{3}{|c|}{$10.4 \pm 4.3$} & \multicolumn{3}{|c|}{$11.0 \pm 4.3$} \\
\hline $\begin{array}{c}\text { Median age } \\
\text { (years) }\end{array}$ & \multicolumn{3}{|c|}{10.5} & \multicolumn{3}{|c|}{11.8} \\
\hline Age groups & $\begin{array}{r}\text { Total } \\
\mathrm{N}(\%)\end{array}$ & $\begin{array}{l}\text { Girls } \\
\mathrm{N}(\%)\end{array}$ & $\begin{array}{l}\text { Boys } \\
\mathrm{N}(\%)\end{array}$ & $\begin{array}{r}\text { Total } \\
\mathrm{N}(\%)\end{array}$ & $\begin{array}{l}\text { Girls } \\
\mathrm{N}(\%)\end{array}$ & $\begin{array}{l}\text { Boys } \\
\mathrm{N}(\%)\end{array}$ \\
\hline $0-<1$ month & 0 & 0 & 0 & 0 & 0 & 0 \\
\hline $\begin{array}{l}\geq 1 \text { month }-<1 \\
\text { year }\end{array}$ & $\begin{array}{c}2 \\
(1.1)\end{array}$ & $\begin{array}{c}1 \\
(0.6)\end{array}$ & $\begin{array}{c}1 \\
(0.6)\end{array}$ & $\begin{array}{c}1 \\
(0.3)\end{array}$ & $\begin{array}{c}1 \\
(0.3)\end{array}$ & 0 \\
\hline$\geq 1-<5$ years & $\begin{array}{c}24 \\
(13.3) \\
\end{array}$ & $\begin{array}{c}14 \\
(7.7)\end{array}$ & $\begin{array}{c}10 \\
(5.5)\end{array}$ & $\begin{array}{c}42 \\
(10.5) \\
\end{array}$ & $\begin{array}{c}24 \\
(6.0)\end{array}$ & $\begin{array}{c}18 \\
(4.5) \\
\end{array}$ \\
\hline$\geq 5-<12$ years & $\begin{array}{c}90 \\
(49.7)\end{array}$ & $\begin{array}{c}51 \\
(28.2)\end{array}$ & $\begin{array}{c}39 \\
(21.5)\end{array}$ & $\begin{array}{c}171 \\
(42.9)\end{array}$ & $\begin{array}{c}81 \\
(20.3)\end{array}$ & $\begin{array}{c}90 \\
(22.5)\end{array}$ \\
\hline$\geq 12-<18$ years & $\begin{array}{c}65 \\
(35.9)\end{array}$ & $\begin{array}{c}28 \\
(15.5)\end{array}$ & $\begin{array}{c}37 \\
(20.4)\end{array}$ & $\begin{array}{c}185 \\
(46.3)\end{array}$ & $\begin{array}{c}101 \\
(25.3)\end{array}$ & $\begin{array}{c}84 \\
(21.1)\end{array}$ \\
\hline
\end{tabular}

In 2011-2013 USG approved diagnosis in 127 (70.2\%) patients, but in 2001-2003 - 15 (3.8\%) patients. In 2011-2013 mesadenitis was not approved by USG in $48(26.5 \%)$ patients, but in 2001-2003 - in 243 (60.9\%). In 20112013 USG was not performed in $6(3.3 \%)$ patients, but in 2001-2003 - 141 (35.3\%) patients. In 2011-2013 AB received 39.8\% patients: 40 (55.6\%; CI 
44.1-67.1) boys and 32 (44.4\%; CI 32.9-55.9) girls, but in 2001-2003-26.6\% patients: 54 (50.9\%; CI 41.4-60.4) boys and 52 (49.1\%; CI 39.6-58.6) girls. In 2011-2013 the most commonly used AB was ampicillin - 61 (51.3\%) prescriptions, but in 2001-2003 - 84 (44.5\%). In 2011-2013 there were 39 (32.2\%) gentamicin prescriptions, but in 2001-2003- 73 (38.6\%). Reason in notes was not written in $22(30.6 \%)$ patients' medical records in 2011-2013 and in $79(74.5 \%)$ patients' medical records in 2001-2003.

\subsubsection{Analysis of antibiotics most commonly used in the mesadenitis treatment}

The Summary contains analysis of ampicillin and gentamicin prescriptions.

\section{Ampicillin}

See Figure 2.9. for the correctness of ampicillin doses.
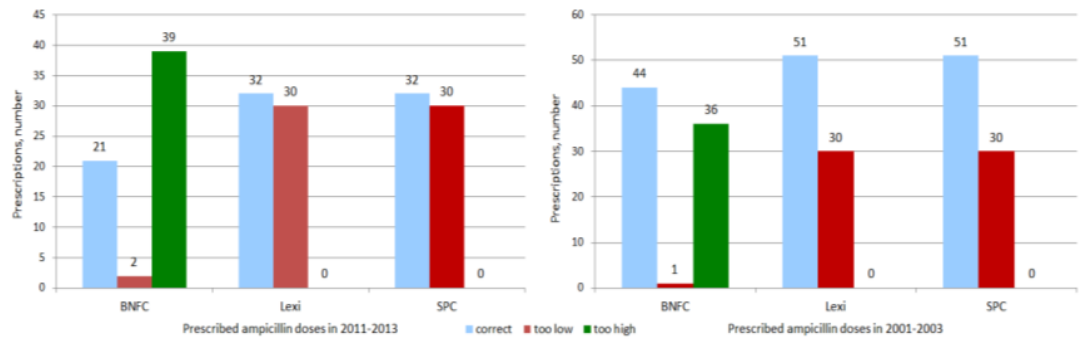

Figure 2.9. Compliance of the prescribed ampicillin doses with BNFC, Lexi and SPC recommendations as of 2011-2013 and 2001-2003

Wrong doses were administered most frequently to children under the age of 12 years: according to SPC, such were $30(81.1 \%)$ prescriptions in 2011-2013 and 30 (60.0\%) prescriptions in 2001-2003. 


\section{Gentamicin}

See Figure 2.10. for the correctness of doses.
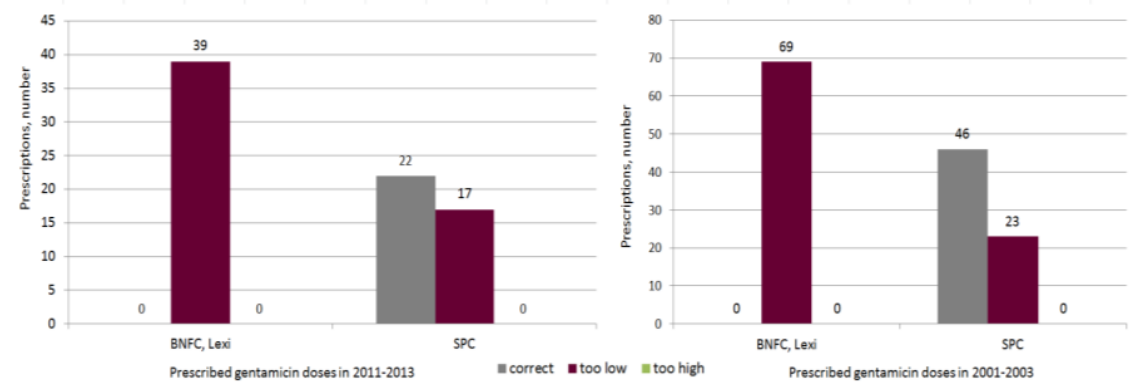

Figure 2.10. Compliance of the prescribed gentamicin doses with BNFC, Lexi and SPC recommendations as of years 2011-2013 and 2001-2003

\subsubsection{Antibiotic off-label use}

The Summary contains analysis of ampicillin and gentamicin off-label use.

\section{Doses not listed in the Summary of Product Characteristics}

\section{Ampicillin}

In 2011-2013 doses not listed in the SPC were prescribed in $30(48.4 \%)$ prescriptions, but in 2001-2003 - in 30 (37.0\%) prescriptions.

\section{Gentamicin}

In 2011-2013 doses not listed in the SPC were prescribed in 17 (43.6\%) prescriptions, but in 2001-2003 - in 23 (33.3\%) prescriptions. 


\section{Timing of administration}

In 2011-2013 ampicillin had wrong administration in regard of timing in 15 (24.2\%) prescriptions, but in 2001-2003 - in 5 (6.0\%) prescriptions. Timing for gentamicin timing of administration was every 12 hours according to SPC (Gentamicin KRKA, 2011, Gentamicin Sopharma, 2014), but not under BNFC and Lexi recommendations.

\subsection{Injuries of upper and lower extremities: patients' characteristics and analysis of the antibiotic usage}

\subsubsection{Characteristics of patients and surgeries, and analysis of the surgical prophylaxis}

Both during the period of 2011-2013 and 2001-2003 the number of hospitalized boys exceeded the number of hospitalized girls more than twice. See Figure 2.11. for the characteristics of patients.

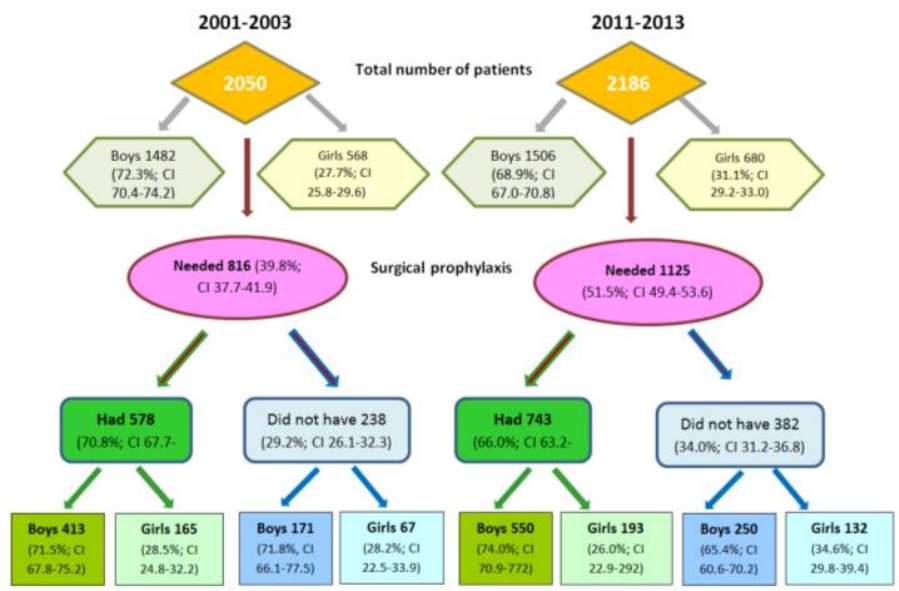

Figure 2.11. Demographic characteristics for the patients with upper and lower extremities (2011-2013 and 2001-2003) 
In 2011-2013 AB were received by 751 (34.4\%; CI 32.4-36.4) patient: 555 (73.9\%; CI 70.8-77.0) boys and 196 (26.1\%; CI 23.0-29.2) girls, but in 2001-2003 - by 654 (31.9\%; CI 29.9-33.9) patients: 472 (72.2\%; CI 68.8-75.6) boys and 182 (27.8\%; CI 24.4-31.2) girls. During both periods of study (20112013 and 2001-2003) the highest number of procedures was the reduction and immobilization without inserting any internal fixation devices (Table 2.6.).

Table 2.6.

Characteristics of surgeries in 2011-2013 and 2001-2003

\begin{tabular}{|c|c|c|}
\hline Year & 2011-2013 & 2001-2003 \\
\hline Surgery & $\mathbf{N}(\%)[95 \% \mathrm{CI}]$ & $\mathbf{N}(\%)[95 \% \mathrm{CI}]$ \\
\hline Total number & 2116 & 1907 \\
\hline $\begin{array}{l}\text { Reduction and immobilization } \\
\text { without internal fixation }\end{array}$ & $\begin{array}{c}962(45.5) \\
{[43.4-47.6]}\end{array}$ & $\begin{array}{l}1016(53.3) \\
{[51.1-55.5]} \\
\end{array}$ \\
\hline $\begin{array}{l}\text { Closed reduction with insertion } \\
\text { of internal fixation devices }\end{array}$ & $\begin{array}{c}928(43.9) \\
{[41.8-46.0]} \\
\end{array}$ & $\begin{array}{c}639(33.5) \\
{[33.4-37.7]} \\
\end{array}$ \\
\hline Open reduction & $226(10.7)[9.4-12.0]$ & $252(24.8)[22.9-26.7]$ \\
\hline $\begin{array}{l}\text { Only immobilization (number } \\
\text { of patients) }\end{array}$ & 140 & 212 \\
\hline
\end{tabular}

In 2011-2013 the highest number of patients who received $A B$ prophylaxis was the age of 5-12 years - 347 (46.7\%) patients, but in 20012003 - from the age of 12-18 years - 293 (50.7\%) patients. In 2011-2013 there were more patients than in 2001-2003 who did not receive AB prophylaxis although it was indicated by the guidelines: 382 (34.0\%) and $238(29.2 \%)$ patients respectively. Statistically this difference was significant (Chi-squared test, $\mathrm{p}<0.05)$. Details on the prophylaxis timing and duration are shown in Table 2.7. 
Table 2.7.

Surgical prophylaxis during the period of 2011-2013 and 20012003

\begin{tabular}{|l|c|c|}
\hline \multicolumn{1}{|c|}{ Year } & $\mathbf{2 0 1 1 - 2 0 1 3}$ & $\mathbf{2 0 0 1 - 2 0 0 3}$ \\
\hline $\begin{array}{c}\text { Information about } \\
\text { prophylaxis }\end{array}$ & $\begin{array}{c}\mathbf{N} \text { (\%) [95\% CI] } \\
\text { (number of prescriptions) }\end{array}$ & $\begin{array}{c}\mathbf{N} \text { (\%) [95\% CI] } \\
\text { (number of prescriptions) }\end{array}$ \\
\hline Too late & $146(19,6)$ & $30(5,2)$ \\
\hline Too early & $184(24,7)$ & $9(1,5)$ \\
\hline On time & $370(49,7)$ & $10(1,7)$ \\
\hline $\begin{array}{l}\text { No information about } \\
\text { timing }\end{array}$ & $44(5,9)$ & $532(91,2)$ \\
\hline 1 dose & $546(73,4)$ & $196(33,7)$ \\
\hline $\begin{array}{l}\text { Multiple doses } \\
\text { administered in } \\
24 \mathrm{~h}\end{array}$ & $153(20,6)$ & $326(56,1)$ \\
\hline$>24 \mathrm{~h}$ & $41(5,5)$ & $52(9,0)$ \\
\hline $\begin{array}{l}\text { No correct information } \\
\text { available }\end{array}$ & $4(0,5)$ & $7(1,2)$ \\
\hline
\end{tabular}

Analysis of surgical prophylaxis according to ECDC quality indicators (Figure 2.12).

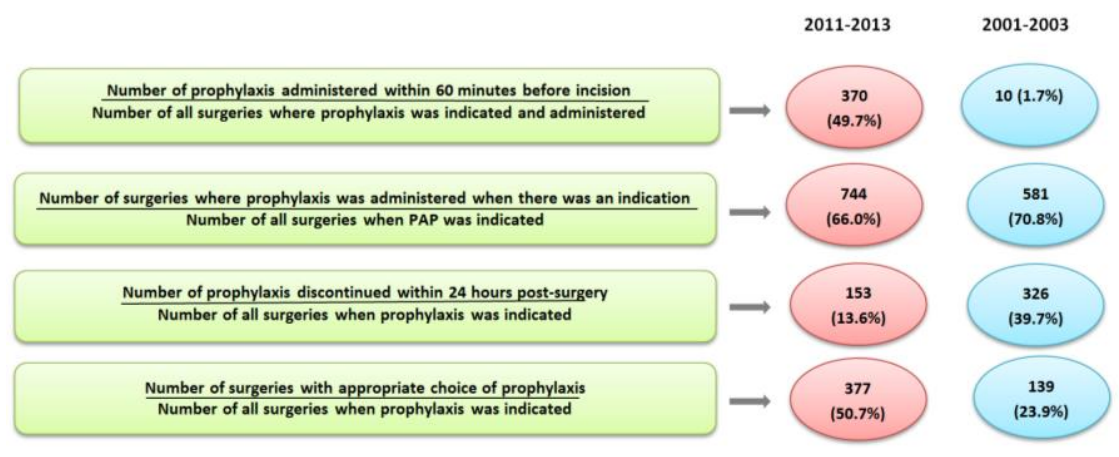

Figure 2.12. Surgical prophylaxis according to ECDC quality indicators during the period of 2011-2013 and 2001-2003. 


\subsubsection{Analysis of the most commonly used antibiotics for surgical prophylaxis}

In 2011-2013 $6 \mathrm{AB}$ were used for prophylaxis, but in 2001-2003 - 4 $\mathrm{AB}$. The most frequently used $\mathrm{AB}$ are indicated in Table 2.8. In 2011-2013 doses were not analysed in $20(2.7 \%)$ prescriptions - the patient's medical charts did not contain any data on the patient's weight. Cefazolin was used in 9 cases, cefuroxime - in 6 and ceftriaxone - in 5. Ampicillin, amoxicillin and oxacillin each was used in one prescription.

Table 2.8.

Three most frequently used AB during the period of 2011-2013 and 20012003

\begin{tabular}{|l|c|c|c|c|}
\hline \multicolumn{1}{|c|}{ Year } & \multicolumn{2}{|c|}{$\mathbf{2 0 1 1 - 2 0 1 3}$} & \multicolumn{2}{c|}{$\mathbf{2 0 0 1 - 2 0 0 3}$} \\
\hline \multicolumn{1}{|c|}{ Antibiotic } & $\mathbf{N ~ ( 7 4 4 )}$ & $\mathbf{\%}$ & $\mathbf{N}(\mathbf{5 8 1})$ & \% \\
\hline Cefazolin & $\mathbf{3 7 7}$ & $\mathbf{5 0 . 7}$ & 139 & 23.9 \\
\hline Cefuroxime & 155 & 20.8 & $\mathbf{4 3 2}$ & $\mathbf{7 4 . 4}$ \\
\hline Ceftriaxone & 209 & 28.2 & 0 & 0 \\
\hline
\end{tabular}

\section{Analysis of cefazolin doses}

According to the hospital's Recommendations in 2011-2013 cefazolin doses were not correct in 217 (59.0\%) prescriptions, but according to Lexi they were not correct in $160(43.5 \%)$ prescriptions and according to the SPC - in $120(32.6 \%)$ prescriptions. According to the hospital's Recommendations in 2001-2003 cefazolin doses were not correct in 35 (34.7\%) prescriptions, but according to Lexi - in $22(21.8 \%)$ prescriptions and according to the SPC - in $23(22.8 \%)$ prescriptions. AB doses were not correct most often in children under the age of 12 years: according to the hospital's Recommendations during the period of 2011-2013 in $152(80.4 \%)$ prescriptions and during the period of $2001-2003$ - in $23(88.4 \%)$ prescriptions. 


\section{Analysis of cefuroxime doses}

According to BNFC and Lexi recommendations, in 2011-2013 cefuroxime doses were not correct in 121 (81.2\%) prescriptions and according to the SPC - in $45(30.2 \%)$ prescriptions, but according to BNFC and Lexi recommendations, in 2001-2003 - in 124 (35.6\%) prescriptions and according to the SPC - in $92(26.4 \%)$ prescriptions. Statistically the difference was significant for BNFC and Lexi recommendations $(\mathrm{p}<0.05)$, but was not significant for the SPC (Chi-squared test, $\mathrm{p}=0.588$ ).

\section{Analysis of ceftriaxone doses}

According to the SPC, in 2011-2013 doses were correct in 160 (78.4\%) prescriptions, but according to BNFC recommendations - only in $88(43.1 \%)$ prescriptions.

\subsubsection{Antibiotic off-label use}

\section{Antibiotic prescriptions outside the indication and patient's age}

In 2011-2013 AB were used for the indications not listed in the SPC in 418 (56.2\%) prescriptions and in 2001-2003 - in 283 (48.7\%) prescriptions.

\section{Antibiotic doses, which do not match the Summary of Product Characteristics}

In 2011-2013 antibiotic doses did not match the SPC in 210 (28.2\%) prescription and in 2001-2003 - in 123 (21.2\%) prescriptions. 


\section{DISCUSSION}

\subsection{The usage of point prevalence surveys in the antibiotic consumption analysis}

In 2003, 2005, 2007 and 2011 there have been conducted several national level PPS in Latvia (Dimina, 2013). Nevertheless, the usage of AB in hospitalized paediatric patients as a separate notion has been analysed only since 2011 as a part of these doctoral thesis. After the development of the ARPEC PPS protocol it became easier to compare the UCH PPS results with the results from hospitals in other countries. Literature provided studies, where the PPS methodology is used, but paediatric patients were quite often analysed together with adults (Ansari et al., 2009, Ansari et al., 2010, Diminga et al., 2009, Thu et al., 2012) or there were different nuances in PPS protocols, e.g., information about $\mathrm{AB}$ doses were not collected (Thu et al., 2012, Xie et al., 2014). The aim of the PPS conduction at the UCH was to find out general trends of $\mathrm{AB}$ usage at the hospital, while focusing on $\mathrm{AB}$ usage trends at the Paediatric Surgery clinic. PPS results show that there is the high use of the $3^{\text {rd }}$ generation cephalosporins, especially ceftriaxone consumption in the $\mathrm{UCH}$ in general (Figure 2.1.). More and more cephalosporin and quinolone use has been linked to development of resistance, as unnecessary use of them may contribute to the development of selection pressure. These are broad-spectrum $A B$, which reaches high concentrations in the body and are excreted for relatively long time. The most appropriate is AB of the narrow-spectrum penicillin group. PPS methodology does not provide explanation for the high use of cephalosporins. The UCH results are similar to the results obtained from other Latvian hospitals where the $3^{\text {rd }}$ generation cephalosporins were among the most frequently used $\mathrm{AB}$ (previously these were the $1^{\text {st }}$ generation cephalosporins) (Diminga, 2013, Diminga et al., 2009). Similar trends were observed in the PPS performed in 
Latvian paediatric hospitals and wards in November 2012 - other $\beta$-lactam AB (and especially the $3^{\text {rd }}$ generation cephalosporins) were the most frequently prescribed AB group - in 101 (50.8\%) prescriptions. Nevertheless, it should be noted that $66.7 \%$ of all analysed patients were the UCH patients.

The route of $\mathrm{AB}$ administration is also one of the quality indicators of the $\mathrm{AB}$ usage. There was the high number of parenterally administrated $\mathrm{AB}$ at the UCH (Figure 2.3.). The switch from parenteral to oral $A B$ depends from the individual choice made by the physician - the hospital does not provide any general recommendations on when such switch should be performed. The usage of parenteral $\mathrm{AB}$ also indicates that the necessity of the $\mathrm{AB}$ usage is not always evaluated after the period of 48-72 hours (Public Health England, 2015).

\section{Strength and limitations of the method}

In PPS necessary information is obtained from the patients' medical documents. Therefore there is less possibility of collecting wrong data than in the case of DDD method were data are obtained from the pharmacy. In addition, unlike the DDD method, where aggregated data (hospital in general or particular ward) are used, in PPS individual (patient specific) data are used. The PPS methodology is useful in situations, when it is necessary to obtain information on $\mathrm{AB}$ use for a specific time period or on $\mathrm{AB}$ usage tendencies (if PPS are repeated). This method could also be used to obtain information on spectrum of used $\mathrm{AB}$ in the hospital in general or in a specific ward in particular. This method does not require substantial financial investment and the PPS protocol is not very complicated, which is important when thinking about specialists who will use this protocol. The PPS has also some limitations, e.g., analysis is performed only on the patients in the PPS who receive AB at a specific point in time, but it is impossible to obtain information on patients, 
who should receive $\mathrm{AB}$ but do not receive them. The PPS does not provide information on the total $\mathrm{AB}$ consumption in a longer period, because it records the situation at a particular point in time. Cross-sectional studies, that also include the PPS, do not allow to analyse the incidence (e.g., time when the AB usage is started).

\subsection{The usage of the methodology of the defined daily dosage in antibiotic consumption studies}

The UCH $\mathrm{AB}$ consumption data were analysed by using DDD (characterises $\mathrm{AB}$ total consumption), $\mathrm{DDD} / 100 \mathrm{BD}$ and $\mathrm{DDD} / 100$ patients (both characterise the intensity of $\mathrm{AB}$ usage). The usage of cephalosporins and especially the $3^{\text {rd }}$ generation cephalosporins has increased (Figure 2.6.). There was no evidence found that the highest seasonal $\mathrm{AB}$ consumption would be in last quarter of the year, when it could be linked with, for example, increase of lower respiratory tract infections. In 2013 the second highest $\mathrm{AB}$ consumption was registered in summer (DDD/100 BD (Figure 2.5.) as well as DDD/100 patients. At the same time the number of treated patients bed-days was the lowest in the $3^{\text {rd }}$ quarter if to be compared with other quarters in 2013. (The $2^{\text {nd }}$ lowest number of treated patients and bed-days was the $4^{\text {th }}$ quarter -4976 and 28009 respectively.) Such results could not be explained by the fact that some chief nurses may build medicines stockpiles in their wards or with administrative (ward therapeutic profile) changes that took place during different quarters as of 2011 and 2012. The UCH had provided results similar to those in Porta et al. study (Porta et al., 2012) by using 90\%DU method - in both the UCH hospital "Tornakalns" and hospitals in the Porta et al. study $90 \% \mathrm{DU}$ made in average $14 \mathrm{AB}$. Average usage of $\mathrm{AB}$ in total was less than in the Porta et al. study - 31 and 47 respectively. Differences were also observed in $\mathrm{AB}$ that accounted for $90 \% \mathrm{DU}$ : amoxicillin all study period was among top 
five AB in the UCH hospital "Tornakalns" (Figure 2.7.), but the Porta et al. study amoxicillin was not among the five most frequently used $\mathrm{AB}$.

\section{Strength and limitations of the methods}

The strength of this method is that it is possible to obtain information about the $\mathrm{AB}$ consumption (DDD) and the intensity of $\mathrm{AB}$ usage (DDD/100 $\mathrm{BD}$ and $\mathrm{DDD} / 100$ patients) in the hospital in general or in the hospital ward or clinic in particular. DDD method similarly to PPS does not require large financial resources to perform the analysis. One of limitations of this method is that it does not show the real $\mathrm{AB}$ consumption, because the DDD is artificially created unit of measurement and does not necessarily reflect the recommended or Prescribed Daily Dose (Haug et al., 2014, Müller et al., 2006). AB consumption analysis in hospital wards complicated situation where the structure of wards changed significantly during 2011-2013: some wards were merged together, some wards changed medical profiles, some wards were closed while the hospital pharmacy continued to count $\mathrm{AB}$ by using the same old administrative ward principle and did not take into account different medical profiles. Therefore there could be a situation that in the ward where previously patients with gastroenterology and endocrinology problems were hospitalized, after the restructuring had not only patients with gastroenterology and endocrinology problems, but also with rheumatology and nephrology problems. But the pharmacy still regarded it just as a ward number four. These administrative changes had negative influence on the quality of results and $\mathrm{AB}$ consumption analysis in wards had not significant value. The Thesis results focused on $\mathrm{AB}$ consumption analysis performed only at the Paediatric Surgery Clinic. In 2006 there were four surgery wards, but in 2013 - remained only two. In 2008-2012 abdominal surgery, gastroenterology and endocrinology 
patients were hospitalized in the same ward, but the hospital pharmacy did not specify, which $\mathrm{AB}$ was received by surgical patients.

The main problem in the context of $\mathrm{AB}$ consumption studies in children is that, although DDD has been one of the most common unit used in measuring $\mathrm{AB}$ use, the measuring of $\mathrm{AB}$ use in paediatrics is a problem. The reason - the WHO DDD methodology is not applicable in children due to the vast differences in body weight within this particular population. There are no established similar analyses principles for $\mathrm{AB}$ consumption analysis established in Latvian hospitals, and almost all consumption studies are voluntary and based on researchers enthusiasm. Nevertheless, this is not a problem only in Latvia, but also in in other countries (Norberg et al., 2014). At the moment hospitals in Latvia can choose to conduct or not to conduct $\mathrm{AB}$ consumption studies, as well as what methodologies use. It was possible to use the DDD method in the Thesis, because one of the tasks was to analyse $\mathrm{AB}$ consumption trends provided by this method.

\subsection{Surgical prophylaxis}

$\mathrm{AB}$ surgical prophylaxis is important quality indicator, which indicates correctness of the $\mathrm{AB}$ usage at the hospital. When analysing $\mathrm{AB}$ use in patients with acute appendicitis and upper and lower extremities injuries it was impossible to use all EDCD (2013) proposed quality indicators, as all necessary information was not always available (e.g., time of $\mathrm{AB}$ administration).

\section{Surgical prophylaxis in PPS}

In all PPS studies, conducted at the $\mathrm{UCH}$, the number of patients that had AB prophylaxis was very low: from $11.8 \%$ in May 2011 to $30.0 \%$ in November 2013. Although in general the number of patients was very low, 
most of them received prophylaxis for more than 24 hours. Such a small number of patients does not allow to draw conclusions on the appropriateness of the surgical prophylaxis, which is based only on PPS results.

\section{Surgical prophylaxis in patients with acute appendicitis}

When comparing results obtained in 2001-2003 and 2011-2013, there are still many patients, who did not receive prophylaxis on time during the period of 2011-2013. 88.7\% or 196 patients did not receive prophylaxis on time in 2001-2003 and $63.6 \%$ or 63 patients in 2011-2013. Situation with the duration of prophylaxis was even worse in patients with diagnosis acute phlegmanous or catarrhal appendicitis who received $\mathrm{AB}$ for longer than 24 hours in 2011-2013 if to be compared with 2001-2003. There were no records in the patients' medical charts regarding the reasons of this prolonged prophylaxis. In addition, the situation with the indication of $\mathrm{AB}$ administration time has also not improved in 2011-2013 if to be compared with 2001-2003. Currently the hospital's Recommendations (Zavadska et al., 2013) state that patients with destructive appendicitis should have $A B$ prophylaxis (cefotaxime). Different international guidelines suggest that $\mathrm{AB}$ prophylaxis is necessary before all appendectomies (both complicated and uncomplicated appendicitis) (Andersen et al., 2005, Daskalakis et al., 2014, Hopkins, 2010, Lee et al., 2010, SCHTA, 2010, SIGN, 2008). According to some authors (Vons et al., 2011), all patients, who have surgery, should receive AB prophylaxis, because routine diagnostic methods cannot guarantee that the patient will or will not have destructive appendicitis. Different $\mathrm{AB}$ are recommended in these guidelines, e.g., UpToDate database recommends that children with nonperforated appendicitis receive a single prophylactic dose of a broad spectrum antibiotic, e.g., cefoxitin, cefotetan, piperacillin/tazobactam, ceftriaxone and metronidazole or gentamicin and either clindamycin or metronidazole in 
patients allergic to penicillins and cephalosporins. Ceftriaxone suggestion is disputable taking into account the long half-life of this $\mathrm{AB}$ especially in situation where no need for further treatment is. Third generation cephalosporin (especially ceftriaxone) use can also lead to an increase in infections due to ESBL and MRSA producing organisms.

\section{Surgical prophylaxis in patients with upper and lower extremities injuries}

In 2011-2013 there were more surgeries with one prophylactic $A B$ dose than in 2001-2003 (Table 2.7). It is a positive tendency that ceftriaxone usage in prophylaxis decreased but cefazolin usage increased in 2011-2013 (Table 2.8). (In 2001-2003 ceftriaxone was not used for prophylaxis.) It is not possible to explain these changes with methods used in this research. The qualitative research is needed to explain why surgeons have changed their prescription habits. If to be compared with the period of 2001-2003, in 2011-2013 there were more patients with open fractures or closed reduction with insertion of internal fixation who did not receive $\mathrm{AB}$ prophylaxis. According to literature these patients should receive prophylaxis and in most cases it is one $A B$ dose (Bratzler et al., 2013, Darouiche et al., 2004, Gosselin et al., 2004, INESSS, 2005, SAAGAR, 2014, SCHTA, 2010, SFAR et al., 2011). There is no consensus among the UCH surgeons on when prophylaxis is necessary and when not. There are also no correct statistical data available in the UCH on how many paediatric patients with SSI were re-hospitalized in the UCH or other hospitals because of SSI. The authors ( $\mathrm{Ng}$ et al., 2012), who analysed surgeons' adherence to guidelines for surgical $\mathrm{AB}$ prophylaxis concluded that there was a wide variation of overall compliance with SAP guidelines, ranging from $0 \%$ to $71.9 \%$. The misuses of prophylactic $\mathrm{AB}$ were common occurrence, particularly in the form of inappropriate choice and prolonged duration of administration. 
Lack of awareness of existing guidelines, influence of initial training, personal preference and influence from colleagues were among the factors, which hindered the surgeons' adherence to guidelines. There is a need for educating the UCH surgeons on the correct AB prophylaxis. The UCH Paediatric Surgery Clinic has the same $A B$ prophylaxis problems as those described in the respective literature (Amadeo et al., 2010, Kesler et al., 1982, Rangel et al., 2011, Voit et al., 2005) (Figure 3.1.).

\section{Prolonged surgical prophylaxis}

Prophylaxis started to early or too late

Unnecessary use of high risk AB (e.g., ceftriaxone)

Avoiding AB prophylaxis when necessary

\section{Figure 3.1. Surgical prophylaxis problems in the UCH Paediatric Surgery Clinic}

\subsection{Patients with acute appendicitis treatment}

In 2011-2013 the percentage of patients with phlegmanous or catarrhal appendicitis, who received $\mathrm{AB}$ for more than 24 hours was higher than in 2001-2003 - 80,2\% (150 patients) and 66.3\% (183 patients) respectively. In the systematic review completed in 2008 the authors concluded that children with uncomplicated (acute or gangrenous), but not perforated, appendicitis can be treated with prophylactic $\mathrm{AB}$ for approximately 24 hours or less (Nadler et al., 2008). The authors also concluded that although the triple AB therapy has been the main standard in paediatric patients, monotherapy with broadspectrum $\mathrm{AB}$ could be equally effective, and quite possibly it could be more 
cost-effective. Also the evidence supports the use of the guidelines in the paediatric population similar to those suggested for the adult population when managing acute appendicitis. It is not possible to ignore the fact that some information, which could justify the prolonged use of $\mathrm{AB}$, was missing from the UCH patients' medical charts as the data were collected retrospectively. However, despite this potential confounder, there was a high number of patients with uncomplicated appendicitis, who have received prolonged $\mathrm{AB}$ therapy.

\subsection{Patients with mesadenitis treatment}

In 2011-2013 there were more patients whose diagnosis was confirmed by the USG than in 2001-2003. It could be explained by the development of the USG technic, as well as more frequent USG use in situations when mesadenitis was suspected. In 2001-2003 there were more cases when the patients' medication charts held no records on reasoning for $\mathrm{AB}$ administration than it was during the period of 2011-2013 (74.0\% and 30.6\%), confirming the results obtained from analysis of cases of acute appendicitis and injuries of upper and lower extremities - not always the physicians had the grounded arguments for the $\mathrm{AB}$ use. In addition, there are still gaps in the patients' medical charts. Although acute mesadenitis treatment does not always require AB treatment (East Cheshire NHS Trust, 2013, Mao clinic, 2013), there was a higher proportion of patients who received $\mathrm{AB}$ in 2011-2013 - 39.8\% (72 patients) than in 2001-2003 - 26.6\% (106 patients). Since the data were collected retrospectively, it was not possible to explain this higher proportion of patients on AB in 2011-2013. 


\section{Historical control group}

Historical control group used in the analysis of patients with acute appendicitis, mesadenitis and injuries of upper and lower extremities has the following advantages: saving of time and resources required to carry out the research because of the same control group of patients with the same diagnoses treated at the UCH. There are also some limitations: a special sensitivity to the selection bias, e.g., changes in diagnostic criteria over the time (e.g., in the mesadenitis diagnostic) and the possibly incomplete information recorded in the patients' medical records (e.g., the high number of patients with injuries of upper and lower extremities in 2001-2003, whose medical records had no information on the time of $\mathrm{AB}$ administration).

\subsection{Resources of the medicines information}

Paediatric information on $\mathrm{AB}$ dosage and indications is often incomplete or even contradictory, e.g., Pamecil (2008) SPC has the following information on paediatric dosage: "children younger than 2 years must use $1 / 4$ the adult dose, children aged 2-10 years must use $1 / 2$ the adult dose. The dose can be calculated more accurately according to body mass, $25 \mathrm{mg}$ to $50 \mathrm{mg} / \mathrm{kg}$ body weight per day". Dose $25-50 \mathrm{mg} / \mathrm{kg} / \mathrm{day}$ is 2-4 times lower than it is established in the SPC of another pharmaceutical company (Pan-ampicillin, 2010) or in BNFC (2013) (Table 3.1.). 
Table 3.1.

\section{Examples of ampicillin doses in different resources of medicines information}

\begin{tabular}{|c|c|c|c|}
\hline $\begin{array}{l}\text { Information } \\
\text { resource }\end{array}$ & $\begin{array}{l}\text { Age and/or } \\
\text { weight }\end{array}$ & $\begin{array}{c}\text { Route of } \\
\text { administration }\end{array}$ & Usage \\
\hline BNFC (2013) & $\begin{array}{c}1 \text { month-18 } \\
\text { years }\end{array}$ & $\mathrm{IV}, \mathrm{IM}$ & $\begin{array}{l}25 \mathrm{mg} / \mathrm{kg} \text { (max } 500 \mathrm{mg} \text { ) every } 6 \mathrm{~h} \\
\text { (dose double in severe infection) }\end{array}$ \\
\hline \multirow{2}{*}{$\begin{array}{l}\text { Lexi } \\
\text { (Takemoto, } \\
\text { 2011) }\end{array}$} & $<12$ years & IV, IM & $\begin{array}{l}100-200 \mathrm{mg} / \mathrm{kg} / \text { day, dividing } \\
\text { every } 6 \mathrm{~h}\end{array}$ \\
\hline & $>12$ years & IV, IM & $\begin{array}{l}500 \text { mg-3 g every } 6 \mathrm{~h} \text {; max dose } \\
14 \text { g/day }\end{array}$ \\
\hline \multirow[t]{2}{*}{$\begin{array}{l}\text { Micromedex } \\
2.0\end{array}$} & $<40 \mathrm{~kg}$ & IV, IM & $\begin{array}{l}50 \mathrm{mg} / \mathrm{kg} / \mathrm{day}, \text { dividing every } \\
6-8 \mathrm{~h}\end{array}$ \\
\hline & $\geq 40 \mathrm{~kg}$ & IV, IM & $500 \mathrm{mg}$ every $6-8 \mathrm{~h}$ \\
\hline \multirow{3}{*}{$\begin{array}{l}\text { Pan- } \\
\text { Ampicillin } \\
\text { (2010) }\end{array}$} & children & & $\begin{array}{l}1 / 2 \text { of the adult dose } 250 \mathrm{mg} \text { every } \\
4-6 \mathrm{~h} \text { or: }\end{array}$ \\
\hline & $\begin{array}{l}\text { children } \\
\text { and infants }\end{array}$ & IM & $50 \mathrm{mg} / \mathrm{kg} /$ day \\
\hline & $\begin{array}{l}\text { children } \\
\text { and infants } \\
\text { (and } \\
\text { neonates) }\end{array}$ & IV & $100-300 \mathrm{mg} / \mathrm{kg} /$ day \\
\hline $\begin{array}{l}\text { Pamecil } \\
(2008)\end{array}$ & $\leq 17$ years & IV & $\begin{array}{l}25-50 \mathrm{mg} / \mathrm{kg} / \mathrm{day} \\
\text { Max IV dose: } 400 \mathrm{mg} / \mathrm{kg} / \mathrm{day} \\
\text { Max total dose per day: } 10-12 \\
\text { g/day }\end{array}$ \\
\hline
\end{tabular}

The dosing principle of $1 / 4$ and $1 / 2$ of the adult dose is similar to the old penicillin V dosing principle described in Ahmed et al. (2011): "big child = half an adult, small child $=$ half a big child, baby $=$ half a small child". $\mathrm{AB}$ doses in BNFC are mostly based on age bands, although weight bands or weight based calculations $(\mathrm{mg} / \mathrm{kg}$ ) are provided for some indications. Lexi (Takemoto, 2011) dosages are mostly based on some age bands and weight (e.g., $<40 \mathrm{~kg}$ or $>40$ kg). Pamecil SPC has a single dose calculation principle for all ages, but PanAmpicillin SPC - two groups: newborns and infants and children, but nothing is said about adolescents. Similar problems are present in other AB (e.g., ceftriaxone) SPC and formularies. The BNFC has a specific dose $50 \mathrm{mg} / \mathrm{kg}$ 
administered once a day (children under the age of 12 years), Lexi has a dose range $50-75 \mathrm{mg} / \mathrm{kg}$ administered once a day or divided dose for twice a day. There are differences in ages from which ceftriaxone could be used (older than 7 days (Takemoto, 2011) or 15 days (Ceftriaxone-BCPP, 2015), from 1 month (Rocephin, 2015)), timing of administration (once or twice a day), when to start using for surgical prophylaxis (e.g., 12 years).

Almost none of medicines data bases, that are widely used in other European hospitals (Meylers Side Effects of Drugs, Micromedex 2.0, Stockley's Drug Interactions), could be used in Latvian hospitals, as these hospitals do not have the respective subscriptions. The use of formularies, such as BNFC and Lexi, depends on whether the individual specialist can afford buying these books.

\subsection{Antibiotic prescription problems at the UCH Paediatric Surgery Clinic}

Incorrectly prescribed doses are among the most common medical errors (Stultz et al., 2015, Wong et al., 2004). The results of the study at the UCH Paediatric Surgery Clinic show that AB doses were prescribed incorrectly more often to patients under the age of 12 years. Usually doses are calculated in accordance with the body mass in this patient group, and thus it is more likely to make a calculation error than in children older than 12 years of age, e.g., cefazolin dose to children under the age of 12 years is $25-100 \mathrm{mg} / \mathrm{kg} / \mathrm{day}$, but starting from 12 years - 250-500 mg every 8 hours (Takemoto, 2011). Electronic prescriptions may help to reduce prescribing errors (Wong et al., 2009). Evaluation of prescribed $A B$ doses was complicated by the fact that

medicines charts for all patients were in the paper forms and only PICU and NICU had the electronic order forms. In addition, at least a part of nurses transfers information about $\mathrm{AB}$ doses from patients medication charts to 
separate paper forms, thus possibly increasing the number of wrong doses. Another problem is overweight patient, as there are no many studies available about medicines dosages regarding this patient group (both children and adults) and only few SPC establish what AB dose should be prescribed in this case. In the UCH study medicines (gentamicin) dose recalculation was performed in one overweight patient. There are two gentamicin solutions for injections registered in Latvia, but only one (Gentamicin Sopharma, 2014) has information what doses should be prescribed to overweight patients.

\subsection{Antibiotic off-label use}

Study results at the UCH Paediatric Surgery Clinic confirmed the data provided by other studies (Cuzzolin et al., 2006, Doherty et al., 2010, Hsu et al., 2009) about AB off-label use. The off-label use of ampicillin, gentamicin, metronidazole, cefazolin, cefuroxime and ceftriaxone was analysed in patients with acute appendicitis. None of these $\mathrm{AB}$, except for ceftriaxone, had a brand name medicine registered at the Latvian Medicines State Agency. There were no united $\mathrm{AB}$ dosages approved by the European Heads of Mediciens Agencies website (HMA, 2014), except for gentamicin and metronidazole. Nevertheless, there was no information indicating that gentamicin could be used for surgical prophylaxis (Gentamicin, 2010). Metronidazole had indication for surgical prophylaxis (Metronidazole, 2010). BNFC and Lexi also had no information indicating that gentamicin could be used for surgical prophylaxis. Cefazolin$B C P P$ (2014) SPC establishes that cefazolin could be used for surgical prophylaxis in adults. Pan-cefazolin (2010) SPC did not specify, which patients' age groups could use it for prophylaxis, but the dose of 2 grams would be too high for children. Similar situation was with the Reflin (2014) SPC patients age groups were not specified, but the dose 1 gram would be too high for most children under the age of 12 years. Axetine (2011) (cefuroxime) SPC 
also did not provide any information on whether or not the $\mathrm{AB}$ could be used in children. Nevertheless, the suggested dose 1.5 grams could be too high for most of children under the age of 12 years and with body weight $<40 \mathrm{~kg}$. Cefuroxime had indication for surgical prophylaxis both with BNFC and Lexi. Neither Pamecil nor Pan-Ampicillin SPCs, as well as BNFC and Lexi, had established that ampicillin would be used for surgical prophylaxis. The Gentamicin Krka (2011) SPC states that "it could be used in postoperative infection prophylaxis after abdominal surgery especially if the urinary tract or intestines were involved". Gentamicin Sopharma (2014) SPC had nothing on surgical prophylaxis. The use of metronidazole in surgical prophylaxis was included in both Metronidazole B. Braun and Metronidazole Fresenius (2014) SPCs.

$\mathrm{AB}$ off-label use (indications for $\mathrm{AB}$ use) at the $\mathrm{UCH}$ Paediatric Surgery Clinic was more common in 2011-2013, except for patients with acute appendicitis, who had more off-label prescriptions in 2001-2003 (90.6\% and 79.9\% prescriptions respectively). All patients (with acute appendicitis, mesadenitis and injuries of upper and lower extremities) had more off-label dose prescriptions in 2011-2013. Patients with injuries of upper and lower extremities had also more off-label indication prescriptions in 2011-2013 than in 2001-2003 (28.2\% and 21.2\% prescriptions respectively). It was not possible to evaluate the appropriateness of ampicillin and gentamicin prescriptions according to the mesadenitis indication, because there was no complete information available on what origin (e.g., viral, bacterial) it was. Paediatric Surgery Clinic study results show that situation with AB off-label use has not improved in 2011-2013 if to be compared with 2001-2003. Methods used in this research do not allow to explain the reasons why the situation remained without any improvement. There is no a requirement in Latvia for the physicians and pharmacists to inform patients about drug off-label use. At present all pharmacists and physicians are free to choose whether to inform 
patients or not about off-label use. Such information could be vital as patients have rights to know about it. In order to provide such information specialists probably would need to have more time for consultations, as well as receive additional training in order to be able to provide such information. 


\section{CONCLUSSIONS}

1. At the $\mathrm{UCH}$ the total $\mathrm{AB}$ consumption expressed in DDD, as well as for DDD/100 patients, has decreased. Nevertheless, AB consumption for DDD/100 GD has increased. Spectrum of the most commonly used $\mathrm{AB}$ also has changed, as the use of $\mathrm{AB}$ from penicillin group has decreased, but the use of high risk $\mathrm{AB}$ (e.g., the $3^{\text {rd }}$ generation cephalosporins and especially ceftriaxone) has increased. This situation may contribute to the development of $\mathrm{AB}$ resistance.

2. If to compare the period of 2011-2013 with 2001-2003, then it was established that there is still high number of incorrect prophylaxis. Also, $\mathrm{AB}$ were used for a longer period of time contrary to the timescale suggested by the international guidelines (in patients with acute appendicitis). In addition, there is still large number of surgeries, where patients did not receive $A B$ prophylaxis although it was recommended (both patients with acute appendicitis and injuries of upper and lower extremities).

3. $\mathrm{AB}$ doses were administered incorrectly mostly for patients under the age of that 12 years. Also there was a high number of cases when there was no records of the reason why $\mathrm{AB}$ was used - mostly with patients having acute appendicitis and mesadenitis.

4. $\quad$ AB off-label use (regardless of particular indication and age, dose and frequency) was observed in patients with acute appendicitis, mesadenitis and injuries of upper and lower extremities, as well as in patients under the age of 12 years and starting from 12 years of age. 


\section{RECOMMENDATIONS}

1. To conduct regular $\mathrm{AB}$ consumption studies both at the $\mathrm{UCH}$ and other Latvian hospitals, which have paediatric wards, in order to obtain information on $\mathrm{AB}$ consumption tendencies. It could help to improve $\mathrm{AB}$ usage in hospitalized children.

2. Along with $\mathrm{AB}$ consumption studies, to conduct regular HAI studies and analysis.

3. To introduce electronic patient records in order to obtain more precise information on actual situation with $\mathrm{AB}$ use and consumption.

4. To introduce SSI monitoring system in order to be informed on the actual number of patients with SSI.

5. To encourage AB use, which would be based on the evidence acquired from surgical prophylaxis and treatment.

6. To improve the situation with information to be included in patients' medical records, thus ensuring that these records contain clearly stated reasons for $\mathrm{AB}$ use.

7. To provide regular training for health-care professionals regarding the correct use of $\mathrm{AB}$.

8. To define official reference documents on medicine dosage at the hospital. 


\section{REFERENCES}

1. Ahmed U, Spyridis N, Wong IC. Dosing of oral penicillins in children: is big child=half an adult, small child=half a big child, baby=half a small child still the best we can do? BMJ. 2011 Dec 15;343:d7803.

2. Amadeo B, Zarb P, Muller A, et al. European Surveillance of Antibiotic Consumption (ESAC) point prevalence survey 2008: paediatric antimicrobial prescribing in 32 hospitals of 21 European countries. J Antimicrob Chemoter. 2010 Oct;65(10):2247-2252.

3. Andersen BR, Kallehave FL, Andersen HK. Antibiotics versus placebo for prevention of postoperative infection after appendicectomy. Cochrane Database Syst Rev. 2005 Jul 20;(3):CD001439.

4. Ansari F, Erntell M, Goossens H, et al. The European Surveillance of Antimicrobial Consumption (ESAC) Point-Prevalence Survey of Antibacterial Use in 20 European Hospitals in 2006. Clin Infect Dis. 2009;49(10):1496-1504.

5. Ansari F, Molana H, Goossens H, et al. ESAC II Hospital Care Study Group. Development of standardized methods for analysis of changes in antibacterial use in hospitals from 18 European countries: the European Surveillance of Antimicrobial Consumption (ESAC) longitudinal survey, 2000-06. J Antimicrob Chemother. 2010 Dec;65(12):2685-2691.

6. Antimikrobiālās rezistences ierobežošanas komisija (ARIK). Nacionālais plāns par antimikrobiālās rezistences ierobežošanu un piesardz̄ịu antimikrobiālo līdzekḷu lietošanu Latvijā 2015.-2018. gadam. 2015.

7. Axetine $750 \mathrm{mg}, 1,5 \mathrm{~g}$ pulveris injekciju un infūziju šķīduma pagatavošanai. Zāļu apraksts. Saskaņots ZVA 10.10.2011. Available: http://www.zva.gov.lv/zaluregistrs [accessed16.01.2014.]

8. Bratzler DW, Dellinger E, Olsen KM, et al. Clinical practice guidelines for antimicrobial prophylaxis in surgery. Am J Health Syst Pharm. 2013 Feb $1 ; 70(3): 195-283$.

9. British National Formulary for Children 2013-2014. Pharmaceutical Press; Revised edition. 12 July 2013, 880 p. ISBN 978-0857110879.

10. Cefazolin-IPP $2 \mathrm{~g}$ pulveris injekciju vai infūziju šķīduma pagatavošanai. Zāḷu apraksts. Saskaņots ZVA 13-02-2014. Available: http://www.zva.gov.lv/zaluregistrs [accessed 15.09.2014.].

11. Cefazolin-Hospira 1 un $2 \mathrm{~g}$, pulveris injekciju vai infūziju šķ̄īuma pagatavošanai. Zāļu apraksts. Saskaņots ZVA 25-04-2014. Available: http://www.zva.gov.lv/zaluregistrs [skatīts 15.09.2014.].

12. Cefazolin-BCPP $1000 \mathrm{mg}$ pulveris injekciju šķīduma pagatavošanai. Zāļu apraksts. Saskaņots ZVA 03.06.2010. Available: http://www.zva.gov.lv/zalu-registrs [accessed 15.09.2014.].

13. Ceftriaxone-BCPP $1000 \mathrm{mg}$ pulveris injekciju vai infūziju šḳiduma pagatavošanai. Zāļu apraksts. Saskaņots ZVA 02-04-2015. Available: http://www.zva.gov.lv/zaluregistrs [accessed 5.07.2015.].

14. Cefuroxime Actavis $1500 \mathrm{mg}$ pulveris injekciju un infüziju šḳiduma pagatavošanai. Zāļu apraksts. Saskaņots ZVA 06.01.2011. Available: http://www.zva.gov.lv/zaluregistrs [accessed 15.01.2014.]. 
15. Cefuroxime MIP $750 \mathrm{mg}$ pulveris injekciju šksīuma pagatavošanai un Cefuroxime MIP 1500 mg pulveris injekciju vai infuziju šķīduma pagatavošanai. Zāḷ apraksts. Saskaņots ZVA 30.04.2010. Available: http://www.zva.gov.lv/zalu-registrs [accessed 16.12.2013.].

16. Ceyhan M, Yildirim I, Ecevit C, et al. Inappropriate antimicrobial use in Turkish pediatric hospitals: a multicenter point prevalence survey. Int J Infect Dis. 2010 January;14(1):e55-61.

17. Cuzzolin L, Atzei A, Fanos V. Off-label and unlicensed pre-scribing for newborns and children in different settings: a review of the literature and a consideration about drug safety. Expert Opin Drug Saf. 2006 Sep;5(5):703-718.

18. Darouiche RO. Treatment of infections associated with surgical implants. N Engl J Med. 2004;350:1422.

19. Daskalakis K, Juhlin C, Påhlman L. The use of pre- or postoperative antibiotics in surgery for appendicitis: a systematic review. Scand J Surg. 2014 Mar;103(1):1420.

20. Davey P, Brown E, Fenelon L, et al. Interventions to improve antibiotic prescribing practices for hospital inpatients. Cochrane Database Syst Rev. 2005 Oct 19(4):CD003543 Review.

21. Dellit TH, Owens RC, McGowan JE Jr, et al. Infectious Diseases Society of America and the Society for Healthcare Epidemiology of America Guidelines for Developing an Institutional Program to Enhance Antimicrobial Stewardship. Clin Infects Dis, 2007;44(2):159-177.

22. Dimiņa E. Antibakteriālo līdzekḷu patēriņš un tā izmaiṇas Latvijas slimnīcās. Disertācija. LU, 2013.

23. Dimiņa E, Kūla M, Caune U, et al. Repeated prevalence studies on antibiotic use in Latvia, 2003-2007. Euro Surveill. 2009 Aug 20;14(33). pii: 19307.

24. Doherty C, Mc Donnell C. Tenfold medication errors: 5 years' experience at a university-affiliated pediatric hospital. Pediatrics. 2012 May;129(5):916-924.

25. East Cheshire NHS Trust. Mesenteric Adenitis. Information for patients, parents and carers. 2013.2 Available: http://www.eastcheshire.nhs.uk/Downloads/Patient\%20information\%20leaflets/Ch ildrens\%20conditions/Mesenteric\%20Adenitis.pdf [accessed 11.05.14.].

26. European Centre for Disease Prevention and Control (ECDC). Systematic review and evidence-based guidance on perioperative antibiotic prophylaxis. Stockholm: ECDC; $2013 . \quad$ Available: http://www.ecdc.europa.eu/en/publications/Publications/Perioperative\%20antibioti c\%20prophylaxis\%20-\%20June\%202013.pdf [accessed 05.07.14.].

27. Gentamicin KRKA $80 \mathrm{mg} / 2 \mathrm{ml}$ šķīdums injekcijām vai infūzijām. Zāḷu apraksts. Saskaņots ZVA 03.03.2011. Available: https://www.zva.gov.lv/zalu-registrs/ [accessed 12.05.13.].

28. Gentamicin Sopharma $40 \mathrm{mg} / \mathrm{ml}$ šķīdums injekcijām vai infūzijām. Zāļu apraksts. Saskaņots ZVA 27.11.2014. Available: https://www.zva.gov.lv/zalu-registrs/ [accessed 12.01.15.].

29. Gentamicin (gentamicin sulphate). Rapporteurs Public Assessment Report for paediatric studies submitted in accordance with Article 45 of Regulation (EC) No1901/2006, as amended. 2010. Available: http://www.hma.eu/fileadmin/dateien/Human_Medicines/CMD_h_/Paediatric_Re 
gulation/Assessment_Reports/Article_45_work-

sharing/Gentamicin_Art.45_PdAR_Update.pdf [accessed 13.02.15.].

30. Gerber JS, Newland JG, Coffin SE, et al Variability in Antibiotic Use at Children's Hospitals. Pediatric, 2010;126(6):1067-1073.

31. Gosselin AR, Roberts I, Gillespie WJ. Antibiotics for preventing infection in open limb fractures. Cochrane Database Syst Rev. 2004;(1):CD003764.

32. Haug JB, Berild D, Walberg M, et al. Hospital- and patient-related factors associated with differences in hospital antibiotic use: analysis of national surveillance results. Antimicrob Resist Infect Control. 2014 Dec 24;3(1):40.

33. Heads of Medicines Agencies (HMA). Article 45 work-sharing. Co-ordination Group for Mutual Recognition and Decentralised Procedures - Human. Available: http://www.hma.eu/269.html [accessed 30.11.14.].

34. Hing WC, Yeoh TT, Yeoh SF, et al. An evaluation of antimicrobial prophylaxis in paediatric surgery and its financial implication. J Clin Pharm Ther. 2005 Aug;30(4):371-381.

35. Hopkins ABX Guide. Surgical prophylaxis. 2010. Available: http://hopkinsabxguide.org/diagnosis/surgical_infections/surgical_prophylaxis.html?contentInst anceId=255354 [accessed 12.06.13.].

36. Hsu B, Brazelton T. Off-label medication use in an academic hospital pediatric critical care unit. Wis Med J 2009;108(7): 343-348.

37. Institut national d'excellence en santé et en services sociaux (INESSS). Antibiotic Prophylaxis in Orthopedic Surgery, 2005. Available: https://www.inesss.qc.ca/fileadmin/doc/CDM/UsageOptimal/Guides-serieII/CdMAntibio2-OrthopedicSurgery-en.pdf [accessed 14.03.13].

38. de Jong J, van den Berg PB, Visser ST, et al. Antibiotic usage, dosage and course length in children between 0 and 4 years. Acta Paediatr. 2009 Jul;98(7):11421148 .

39. Kesler RW, Guhlow LJ, Saulsbury FT. Prophylactic antibiotics in pediatric surgery. Pediatrics.1982 January;69(1):1-3.

40. Lee SL, Islam S, Cassidy LD, et al. Antibiotics and appendicitis in the pediatric population: an American Pediatric Surgical Association Outcomes and Clinical Trials Committee systematic review. J Pediatr Surg. 2010 Nov;45(11):2181-2185.

41. MacKenzie FM, Monnet DL, Gould IM. Relationship between the number of different antibiotics used and the total use of antibiotics in European hospitals. J Antimicrob Chemother. 2006 Sep;58:657-660.

42. Mao clinic. Mesenteric lymphadenitis: Treatments and drugs. 2013. Available: http://www.mayoclinic.org/diseases-conditions/mesenteric-

lymphadenitis/basics/treatment/con-20029694 [accessed 11.05.14.].

43. McLoughlin A, O'Morain C. Effectiveness of antiinfectives. Chemotherapy. 2005;51:243-246.

44. Metronidazole B. Braun $5 \mathrm{mg} / \mathrm{ml}$ šķīdums infūzijām. Zāḷu apraksts. Saskaņots ZVA 06.03.2014. Available: https://www.zva.gov.lv/zalu-registrs/ [accessed 12.01.15.].

45. Metronidazole Fresenius 0,5\% šķīdums infūzijām. Zāḷu apraksts. Saskaņots ZVA 23.10.2014. Available: https://www.zva.gov.lv/zalu-registrs/ [accessed 12.01.15.].

46. Metronidazole/Metronidazole + Spiramycin. Rapporteurs Public Assessment Report for paediatric studies submitted in accordance with Article 45 of 
Regulation (EC) No1901/2006, as amended. Available: http://www.hma.eu/fileadmin/dateien/Human_Medicines/CMD_h_/Paediatric_Re gulation/Assessment_Reports/Article_45_work-

sharing/Metronidazole_metronidazole__spiramycin_2010_12_45_PdAR.pdf [accessed 13.02.15.].

47. Müller A, Monnet DL, Talon D, et al. Discrepancies between prescribed daily doses and WHO defined daily doses of antibacterials at a university hospital. Br J Clin Pharmacol. 2006 May;61(5):585-591.

48. Nadler EP, Gaines BA. The Surgical Infection Society guidelines on antimicrobial therapy for children with appendicitis. Surg Infect (Larchmt). 2008 Feb;9(1):7583.

49. National institute for Health and Clinical Excellence (NICE). National Collaborating Centre for Women's and Children's Health. Surgical site infection prevention and treatment of surgical site infection. 2008 October. Available: http://www.nice.org.uk/guidance/cg74/chapter/1-recommendations [accessed 02.05.12.].

50. Neubert A, Wong ICK, Bonifazi A, et al. Defining off-label and unlicensed use of medicines for children: Results of a Delphi survey. Pharmacol Res. 2008 NovDec;58(5-6):316-322.

51. Ng RS, Chong CP. Surgeons' adherence to guidelines for surgical antimicrobial prophylaxis - a review. Australas Med J. 2012;5(10):534-540.

52. Norberg S, Struwe J, Grunewald M, et al. A pilot study of risk adjustment for benchmarking antibiotic use between hospitals in Sweden. J Global Antimicrob Resist. 2014;2(1):39-42.

53. Pamecil $1 \mathrm{~g}$ pulveris injekciju šķīduma pagatavošanai. Zāḷu apraksts. Saskaņots ZVA 11244-031108. Available: http://www.zva.gov.lv/zalu-registrs/ [accessed 25.11.14.].

54. Pan-Ampicllin $500 \mathrm{mg}$ un $1 \mathrm{~g}$ pulveris injekciju šķīduma pagatavošanai. Zāḷu apraksts. Saskaņots ZVA 02.12.2010. Available: http://www.zva.gov.lv/zaluregistrs/ [accessed 25.11.14.].

55. Pan-Cefazolin 1g pulveris injekciju šķīduma pagatavošanai. Zāḷu apraksts. Saskaņots ZVA 08.04.2010. Available: http://www.zva.gov.lv/zalu-registrs [accessed 15.09.14.].

56. Paterson DL. The role of antimicrobial management programs in optimizing antibiotic prescribing within hospitals. Clin Infect Dis. 2006 Jan 15;42(2):90-95.

57. Porta A, Esposito S, Menson E, et al. Off-label antibiotic use in children in three European countries. Eur J Clin Pharmacol. 2010 Sep;66(9):919-927.

58. Porta A, Hsia Y, Doerholt K, et al. Comparing neonatal and paediatric antibiotic prescribing between hospitals: a new algorithm to help international benchmarking. J Antimicrob Chemother. 2012 May;67(5):1278-1286.

59. Public Health England. Start Smart Then Focus. 2015. Available: https://www.gov.uk/government/uploads/system/uploads/attachment_data/file/417 032/Start_Smart_Then_Focus_FINAL.PDF [accessed 15.05.2015.].

60. Rangel SJ, Fung M, Graham DA, et al. Recent trends in the use of antibiotic prophylaxis in pediatric surgery. J Pediatr Surg. 2011 Feb;46:366-371. 
61. Raveh D, Yinnon AM, Broide E, et al. Susceptibilities of ESCL-producing Enterobacteriaceae to ertapenem, meropenem and piperacillin-tazobactam with and without clavulanic acid. Chemotherapy. 2007;53:185-189.

62. Reflin 1 g pulveris injekciju šķīduma pagatavošanai. Zāļu apraksts. Saskaņots ZVA 26.06.2014. Available: http://www.zva.gov.lv/zalu-registrs/ [accessed 07.08.14.].

63. Rocephin $1 \mathrm{~g}$ pulveris injekciju šķīduma pagatavošanai. Zāḷu apraksts. Saskaņots ZVA 27.05.2010. Available: http://www.zva.gov.lv/zalu-registrs/ [accessed 25.01.14.].

64. Rocephin $1 \mathrm{~g}$ pulveris injekciju šķīduma pagatavošanai. Zāḷu apraksts. Saskaņots ZVA 27.03.2015. Available: http://www.zva.gov.lv/zalu-registrs/ [accessed 20.04.15.].

65. Schindler C, Krappweis J, Morgenstern I, et al. Prescriptions of systemic antibiotics for children in Germany aged between 0 and 6 years. Pharmacoepidemiol Drug Saf. 2003 Mar;12(2):113-120.

66. Scottish Intercollegiate Guidelines Network (SIGN). Antibiotic prophylaxis in surgery. Edinburgh: SIGN; 2008. (SIGN publication no.104). [July 2008]. Updated April 2014. Available: http://www.sign.ac.uk [accessed 14.09.14].

67. Starptautiskās statistiskās slimību un veselības problēmu klasifikācijas Desmitā redakcija (SSK-10). Available: http://www.spkc.gov.lv/ssk/ [accessed 02.02.2012. and 15.04.15.].

68. Stultz JS, Porter K, Nahata MC. Prescription order risk factors for pediatric dosing alerts. Int J Med Inform. 2015 Feb;84(2):134-140.

69. Swedish Council on Health Technology Assessment (SCHTA). Antibiotic Prophylaxis for Surgical Procedures: Systematic Review, 2010. ISBN: 978-9185413-36-2.

70. Taketomo CK. Pediatric \& Neonatal Dosage Handbook. Lexi-Comp; 18 edition. 2011, 1902 p. ISBN: 978-1591952978.

71. Teibe U. Bioloǵiskā statistika. Rīga: LU Akadēmiskais apgāds, 2007. 156 lpp. ISBN: 9984802574.

72. Thu TA, Rahman M, Coffin S, et al. Antibiotic use in Vietnamese hospitals: a multicenter point-prevalence study. Am J Infect Control. 2012 Nov;40(9):840844.

73. Tönz M, Schmid P, Kaiser G. Antibiotic Prophylaxis for Appendectomy in Children: Critical Appraisal. World J Surg. 2000 Aug;24(8):995-998.

74. Versporten A, Sharland M, Bielicki J, et al. The antibiotic resistance and prescribing in European Children project: a neonatal and pediatric antimicrobial web-based point prevalence survey in 73 hospitals worldwide. Pediatr Infect Dis J. 2013 Jun;32(6):e242-253.

75. Voit SB, Todd JK, Nelson B, et al. Electronic surveillance system for monitoring surgical antimicrobial prophylaxis. Pediatrics. 2005 Dec;116(6):1317-1322.

76. Vons C, Barry C, Maitre S, et al. Amoxicillin plus clavulanic acid versus appendicectomy for treatment of acute uncomplicated appendicitis: an open-label, non-inferiority, randomised controlled trial. Lancet. 2011 May 7; 377(9777):1573-1579.

77. WHO Collaborating Centre for Drug Statistics Methodology (WHOCC). Available: http://www.whocc.no/atc_ddd_index/_[accessed 12.02.14.]. 
78. WHO. Antimicrobial resistance: global report on surveillance. 2014. Available: http://apps.who.int/iris/bitstream/10665/112642/1/9789241564748_eng.pdf?ua=1 [accessed 10.11.2014.].

79. Wong IC, Wong LY, Cranswick NE. Minimising medication errors in children. Arch Dis Child. 2009 Feb;94(2):161-164.

80. Wong IC, Ghaleb MA, Franklin BD, et al. Incidence and nature of dosing errors in paediatric medications: a systematic review. Drug Saf. 2004;27(9):661-670.

81. Xie DS, Xiang LL, Li R, et al. A multicenter point-prevalence survey of antibiotic use in 13 Chinese hospitals. J Infect Public Health. 2014 Aug 13. pii: S18760341(14)00101-4.

82. Zavadska D un BKUS Racionālas antimikrobās terapijas uzraudzības komiteja. Rekomendācijas antibakteriālo līdzekl̦u lietošanai ķirurǵiskajā profilaksē [BKUS rekomendācijas]. 2013.

83. Zhang W, Shen X, Wang Y, et al. Antibiotic use in five children's hospitals during 2002-2006: the impact of antibiotic guidelines issued by the Chinese Ministry of Health. Pharmacoepidemiol Drug Saf. 2008;17(3):306-311a.

84. Zhang W, Shen X, Bergman U, et al. Drug utilisation 90\% (DU90\%) profiles of antibiotics in five Chinese children's hospitals (2002-2006). Int J Antimicrob Agents. 2008 Sep;32(3):250-255b. 


\section{PUBLICATIONS AND THESIS}

\section{PUBLICATIONS}

\section{Doctoral thesis is based on following international publications:}

1. Sviestina I, Aston J, Lorrot M, Mozgis Dz. A comparison of antibiotic use in three specialist paediatric hospitals in France, Latvia and the UK. Eur J Hosp Pharm. 2015;22:132-137.

2. Sviestina I, Mozgis Dz. Evaluation of the antibiotic use for surgical prophylaxis in paediatric acute appendicitis. J Young Pharm. 2015;7(1):7-11.

3. Sviestina I, Mozgis Dz. Antimicrobial usage among hospitalized children in Latvia: a neonatal and pediatric antimicrobial point prevalence survey. Medicina (Kaunas). 2014:175-181.

4. Versporten A, Sharland M, Bielicki J, Drapier N, Vankerckhoven V, Goossens H and the ARPEC project group members: [..] Sviestina I [..]. The Antibiotic Resistance and Prescribing in European Children (ARPEC) Project: A Neonatal and Paediatric Antimicrobial web-based Point Prevalence Survey in 73 Hospitals worldwide. Pediatr Infect Dis J. 2013 Jun;32(6):e242-253.

5. Sviestina I, Aston J, Mozgis Dz. A Comparison of Antimicrobial Prescribing Between Two Specialist Paediatric Centres in the UK and Latvia. Eur J Hosp Pharm 2013;20:180-184.

6. Sviestina I. Trends in Antibiotic Use at the University Children's Hospital in Latvia During 2005-2009. Medicina (Kaunas). 2011;47(Suppl 2):91-96. 


\section{Doctoral thesis is based on following local publications}

1. Rasnača K., Grope I., Sviestiṇa I., Pavāre J., Rasnačs O., Gardovska D. Punkta prevalences pētījums par antibakteriālo līdzekḷu lietošanu Bērnu Klīniskajā Universitātes slimnīcā Latvijā. RSU Zinātniskie raksti 2011. 2. sējums. 2012. 20.-25.lpp. ISBN: 9789984793092.

\section{THESIS}

\section{Results are reported in the following international conferences:}

1. Sviestina I, Mozgis Dz. Antibiotic Consumption at the University Childrens' Hospital in 2006-2014. FIP congress, Düsseldorf, Germany, 29.09.-3.10.15. Poster and thesis.

2. Sviestina I. Correct use of antibiotics. $3^{\text {rd }}$ Baltic Pediatric congress, Riga, Latvia, 19.-21.08.15. Oral presentation.

3. Sviestina I, Mozgis Dz. The impact of hospital antibiotic guidelines on surgical prophylaxis in paediatric patients suffering upper and lower extremity injuries. EAHP congress, Hamburg, Germany, 25.-27.03.15. Poster and thesis (Eur J Hosp Pharm 2015;22:A28-A29).

4. Sviestina I Mozgis Dz. Evaluation of the antibiotic use for surgical prophylaxis in paediatric acute non-perforated appendicitis. ESCP congress, Copenhagen, Denmark, 22-24.10.14. Poster and thesis (Available: http://www.bdp-

congress.dk/ESCP2014/img/ESCP_Copenhagen_2014_Abstractbook_1410 07.pdf, P. 101).

5. Sviestina I, Mozgis Dz. The use of antibiotics for surgical prophylaxis in hospitalized children at the University Children's Hospital. FIP congress, Bangkok, Thailand, 31.08.-4.09.14. Poster and thesis (Available: http://www.fip.org/abstracts?page=abstracts\&action=generatePdf\&item=10 860). 
6. Sviestina I, Aston J, Lorrot M, Goossens H, Sharland M, Versporten A, Mozgis Dz. Antibiotic prescribing for medical prophylaxis - a comparison of practice in the UK, France and Latvija. ESPID congress, Dublin, Ireland, 6-10.05.14. Poster and thesis (Pieejams:

http://espid2015.kenes.com/PublishingImages/scientific-information/espidabstracts/ESPID\%202014\%20abstracts.pdf).

7. Sviestina I, Aston J, Lorrot M, Prot-Labarthe S, Angoulvant F, Doit C, Mozgis Dz. Comparison of Antibiotic Prescribing for Paediatric Lower Respiratory Tract Infection in Three Paediatric Hospitals in the UK, France and Latvia. EAHP congress, Barcelona, Spain, 26-28.03.14. Poster and thesis. (Eur J Hosp Pharm 2014:21(Suppl 1):A1-224)

8. Sviestina I, Mozgis Dz. The use of antibiotics in children with acute appendicitis at the University Children's Hospital. FIP congress, Dublin, Ireland, 31.08.-5.09.13. Poster and thesis (Available: http://fip.org/abstracts2012?page=abstracts2012\&action=generatePdf\&item $=8808$ ).

9. Sviestina I, Goossens H, Sharland M, Versporten A, Mozgis Dz. The Neonatal and Paediatric Antimicrobial Point Prevalence Survey: Antimicrobial Usage in Latvian Hospitals in 2012. ESPID congress, Milan, Italy 28.05.-1.06.13. Poster, oral presentation and thesis (Available: http://w3.kenes-group.com/apps/espid2013/abstracts/pdf/947.pdf).

10. Sviestina I, Mozgis Dz. Point prevalence studies at the Children's University Hospital. EAHP congress, Paris, France, 13-15.03.13. Poster and thesis. (Eur J Hosp Pharm 2013:20(Suppl 1):A220-221).

11. Sviestina I, Aston J, Mozgis Dz. Antibacterial drug use in hospitalised paediatric patients: a comparison between the UK and Latvia. FIP congress, Amsterdam, Netherlands, 3-8.10.12. Poster and thesis (Available: http://www.fip.org/abstracts?page=abstracts\&action=item\&item=7440). 
12. Sviestina I, Mozgis Dz. Antibiotic usage in hospitalised children treatment: retrospective observational study in the infectious diseases unit at the Children University Hospital. EAHP congress, Milan, Italy, 21-23.03.12. Poster and thesis. (Eur J Hosp Pharm 2012;19:2 261).

13. Sviestina I. Antibiotic consumption studies in the Latvian State Children's University Hospital. BARN workshop, Vilnius, Lithuania, 30.11.-1.12.11. Oral presentation.

14. Sviestinga I. Antibiotic Prescribing Tendencies in the Children Clinical University Hospital “Tornakalns”. FIP congress, Istanbul, Turkey, 3.8.09.09. Poster and thesis. (Thesis book (2009)).

15. Sviestina I. The main tendencies in the use of antibiotics in the Children hospital (2005-2008). ACCP and ESCP congress, Orlando, USA, 2428.04.09. Poster and thesis. (Thesis book (2009)).

16. Sviestina I, Pujate E. Use of Antibiotics in the Children Hospital “Gailezers" in Riga, Latvia (2005-2007). 68. FIP congress, Basel, Switzerland, 29.08.-4.09.08. Poster, oral presentation and thesis. (Thesis book (2008)).

\section{Results are reported in the following local conferences:}

1. Sviestiṇa I, Mozgis Dz. Antibiotiku patēriṇa analīze Bērnu klīniskajā universitātes slimnīcā laikposmā no 2006. līdz 2013. gadam. RSU Scientific conference, Riga, Latvia, 26.03.15. Poster and thesis (Available: http://www.rsu.lv/images/stories/zk2015/antibiotiku_paterina_analize.pdf).

2. Mozgis Dz., Sviestiņa I., Baltiņš M. Dr. med. Pauls Klemms un viņa redzējums vairāku ķirurǵisko slimību gadījumā laikā ap 19. un 20. gs. miju. University of Latvia $73^{\text {rd }}$ conference, Riga, Latvia, 25.01.15. Oral presentation. 
3. Sviestiṇa I. Antibakteriālo līdzekḷu patēriṇa salīdzinoša analīze bērniem stacionārā biežāko ķirurgisko slimību gadījumos. Pharmacists' Society of Latvia conference, Riga, Latvia, 22.11.14. Oral presentation.

4. Sviestina I, Aston J, Mozgis Dz. Analysis of Antimicrobial Prescribing at Two Specialist Paediatric Centres in the UK and Latvia. RSU Scientific conference, Riga, Latvia, 10-11.04.14. Poster and thesis (Available: 14020_Tezes_2014_A4_CS6.indd http://www.rsu.lv/images/stories/zk2014/Analysis_of_Antimicrobial_Prescr ibing.pdf).

5. Selecka K, Nokalna I, Zavadska D, Sviestiṇa I. Bērnu KUS antibakteriālās terapijas nozīmēšanas/maiņas veidlapas aizpildīšanas izvērtējums. RSU Scientific conference, Riga, Latvia, 10-11.04.14. Thesis (Available: 2014.14-020_Tezes_2014_A4_CS6.indd 226. http://www.rsu.lv/images/stories/zk2014/BKUS_antibakterialas_terapijas.p df).

6. Sviestiņa I, Mozgis Dz. Antibiotiku prevalences pētījumi bērniem Latvijas stacionāros 2011.-2012. - Latvian Physicians' $7^{\text {th }}$ congress, Riga, Latvia, 19-21.09.13. Poster and thesis (Available: http://www.arstukongress.lv/?\&s=1361881321\&fu=read\&id=5). 